SHINING A LIGHT ON SOLAR ENERGY IN ONTARIO'S PLANNING PROCESS:

LESSONS FROM INTERNATIONAL BEST PRACTICES IN SOLAR ENERGY

By

Elisa Katrine Bernier

BSc (AgEnvSc), McGill University, 2010

\author{
A Major Research Paper \\ presented to Ryerson University \\ in partial fulfillment of the requirements for the degree of \\ Master of Planning \\ in \\ Urban Development
}

Toronto, Ontario, Canada, 2015

(c) Elisa Bernier 2015 


\section{Author's Declaration for Electronic Submission of a MRP}

I hereby declare that I am the sole author of this MRP. This is a true copy of the MRP, including any required final revisions.

I authorize Ryerson University to lend this MRP to other institutions or individuals for the purpose of scholarly research.

I further authorize Ryerson University to reproduce this MRP by photocopying or by other means, in total or in part, at the request of other institutions or individuals for the purpose of scholarly research.

I understand that my MRP may be made electronically available to the public. 


\title{
SHINING A LIGHT ON SOLAR ENERGY IN ONTARIO'S PLANNING PROCESS: LESSONS FROM INTERNATIONAL BEST PRACTICES IN SOLAR ENERGY
}

\author{
(C) Elisa Bernier, 2015 \\ Master of Planning \\ in \\ Urban Development \\ Ryerson University
}

\begin{abstract}
Solar energy is being heralded as a renewable, abundant and increasingly costeffective source of energy. The Ministry of Energy has made great strides promoting renewable energies such as solar power through the introduction of the Green Energy Act. The 'elephant in the room' that remains to be addressed is the role of land use planning in enabling solar energy generation in urban Ontario. In light of provincial plan updates, the Province has a unique window to think about solar energy in urban planning and to help its municipalities become 'solar ready'. The purpose of this paper is to identify transferable lessons from international best practices in order to derive key recommendations for the province. With provincial support, municipalities can develop plans and regulations that will maximize solar energy potential and ensure its long-term viability in their communities.
\end{abstract}

Key words:

Solar energy, urban planning, Ontario, solar design, climate change 


\section{Acknowledgements}

I would like to extend my greatest gratitude to my supervisor Dr. Pamela Robinson and my second reader Dr. Miljana Horvat. Both were instrumental in introducing me to this new concept of solar energy in urban planning. I am thankful for the knowledge and guidance they shared with me as I worked through this exploratory research in the Ontario context.

Completing my degree and major research paper would not have been possible without the support from my wonderful family, friends and graduating cohort. Finally I would like to extend a warm thank you to my dear family friend Helen who motivated me and provided me with advice throughout my academic career. 
Table of Contents

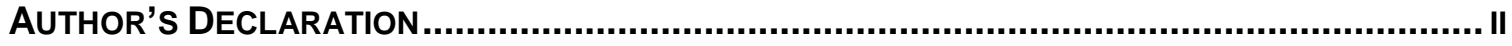

ABSTRACT

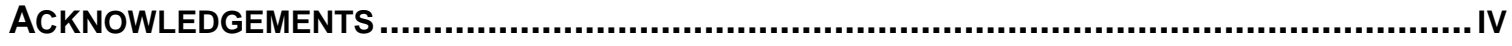

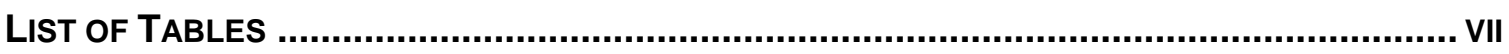

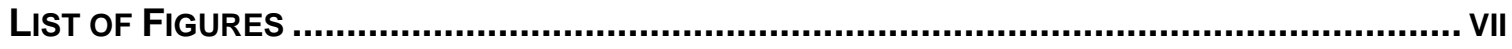

1 INTRODUCTION

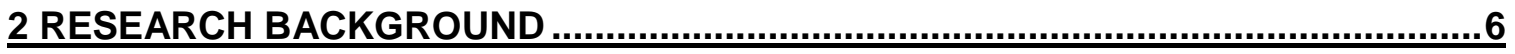

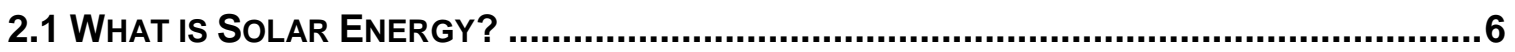

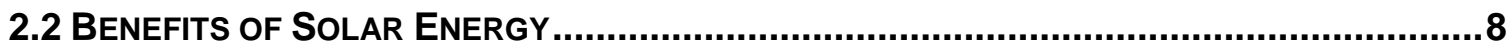

2.3 How DOES PlanNING fOR SOLAR ENERGy WORK IN ONTARIO? ...............................12

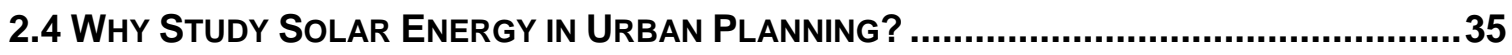

3 METHODOLOGY

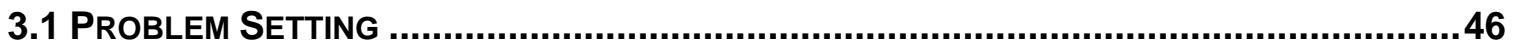

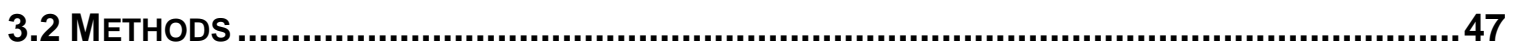

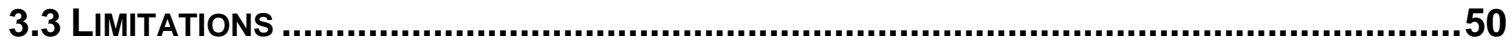

4 PROBLEM INVESTIGATION

4.1 Priorities from the Provincial Policy Statement ..............................................52

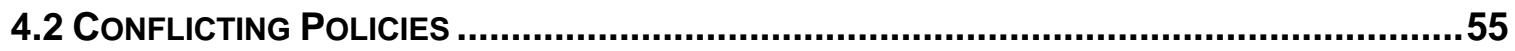

4.3 ANALYSIS OF INTERNATIONAL BEST PractiCES......................................................57

4.4 Commonalities amongst Best Practices........................................................

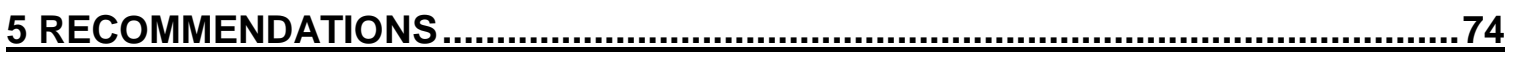

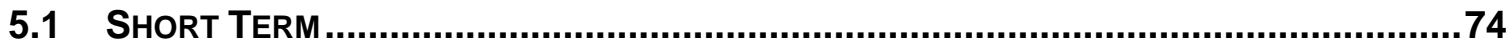




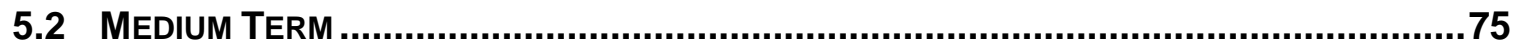

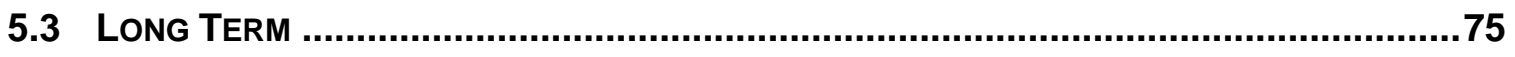

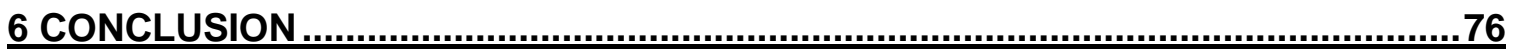

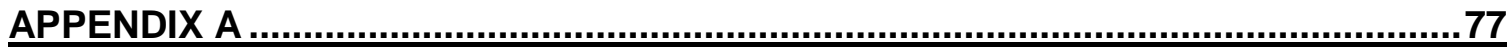

APPENDIX B

REFERENCE LIST 


\section{List of Tables}

Table 1 Lessons from utilizing transportation infrastructure for solar energy production 61

Table 2 Lessons from utilizing brownfields for solar energy production 63

Table 3 Lessons from internationally recognized sustainable cities using solar energy .66

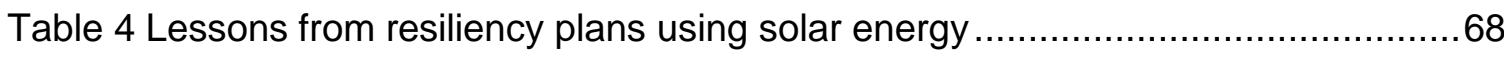

Table 5 Lessons from municipalities reducing greenhouse gas emissions through solar energy programs

\section{List of Figures}

Figure 1 Land use planning in Ontario 20 


\section{Introduction}

Weaning off of non-renewable energy is key to reducing greenhouse gas emissions, pollution and providing reliable long-term energy sources. Despite efforts to reduce emissions through climate change mitigation policies, global carbon dioxide emissions still increased by 1 gigatonne between 2000 and 2010 and are expected to continue growing (Intergovernmental Panel on Climate Change [IPCC], 2014), thereby contributing significantly to global surface temperature increases (IPCC, 2014, p. 8). In an attempt to address Canada's carbon footprint, the federal government committed to reducing its greenhouse gas emissions by $17 \%$ (based on 2005 levels) by the year 2020 with the signing of the Copenhagen Accord (Environment Canada, 2013). These commitments funnel down to the provincial and local governments, compelling public bodies to determine effective and proactive programs to promote energy conservation and efficiency in order to curb carbon emission production.

The Ministry of Energy of Ontario expects to reduce its greenhouse gas emissions by 15\% below 1990s levels by 2020 (Ontario Ministry of Environment [OMOE], 2007). This decrease in greenhouse gas emission is expected to be achieved in part by provincial efforts "to offset almost all of the growth in electricity demand by 2032 using programs and improved codes and standards" that will reduce pressures to provide new energy supply (Ontario Ministry 
of Energy, 2013, p.4). These changes are to occur as the provincial population grows to 17.4 million in the same time span (Ontario Ministry of Finance [MOF], 2013).

One of the sources of energy that is gaining popularity is solar energy. It is a renewable and abundant energy source that can be captured through a wide range of technologies. Within the last few years alone, the prices of these technologies have dropped by $75 \%$ since 2009 rates internationally (International Renewable Energy Agency [IRENA], 2014). In light of provincial programs such as the Feed- in-Tariff, as well as the versatility of grid incorporation, solar panel use on school rooftops and by private property owners, for example, has markedly increased.

The surrounding environment can greatly impact an individual building's ability to conserve energy through passive design principles or to generate electricity from solar energy. Solar energy, more than any other renewable energy source, requires careful planning of infrastructure at a neighbourhood scale, as its potential relies heavily on the orientation and form of the built environment (American Planning Association [APA], 2014; Hachem, Athienitis \& Fazio, 2011; Identification and mobilization of Solar Potential via Local Strategies, 2012 [POLIS]; Kanters \& Horvat, 2012; Vandevyvere \& Stremke, 2012; Van Esch, Looman, \& de Bruin-Hordijk, 2012). This land use and energy planning link has to be strengthened, given that 
solar power demand will continue to grow and is expected to become the most significant contributing source to electricity production by 2050 in the world (International Energy Agency [IEA], 2014). This would require the careful and detailed design of the neighbourhood scale to maximize the potential to generate and conserve energy using the sun. This paradigm shift in site planning is what Vandevyvere and Stremke (2012) discuss as "energy conscious spatial planning" (p. 1324). Intentional energy considerations in land use planning can lead to robust policies that enable energy conservation and solar energy generation.

Presently, the literature reveals that land use planning and policies have been lacking in the solar energy promotion dialogue. International reviews of solar energy policies have mainly focused on financing; grid capacity and technological advances (Solangi et al., 2011; Desmuhk et al., 2011; Timilsina et al., 2012), albeit recognizing the need for more policies that encourage solar energy in the built environment (Solangi et al., 2011, p. 2156).

The U.S. Department of Energy's SunShot Initiative Partnership, which includes multiple organizations such as the American Planning Association, has made great strides in carving out a space for solar energy in the land use-planning sector. It remains that the Canadian counterpart has yet to become actively involved in promoting solar energy in urban planning. Generally speaking, although guidelines are being published with an emphasis on 'solar ready' 
design at the residential scale (e.g. Natural Resource Canada Solar Ready Guidelines, 2013);

they remain voluntary and are typically applied in an ad hoc fashion (Droege, 2006).

Building on Ontario's reputation as a leader in the solar energy industry from the introduction of the Green Energy and Green Economy Act (also known as Green Energy Act or GEA) and successful Feed-in-Tariff (FIT) program, this paper seeks to define how land use regulatory tools and policies can further bolster the solar energy movement and ensure its longterm viability. This paper is presented at an opportune time, in the wake of restoring aging infrastructure and during a period of accelerated advances in solar technology and energy storage. Furthermore, the Growth Plan for the Greater Golden Horseshoe (GPGGH), the Greenbelt Plan and Ontario's Adaptation Strategy and Action Plan, are being reviewed, providing a unique policy window to review and provide recommendations as to how solar energy can be further promoted. The purpose of this paper is to define the role of land use planning with regard to solar energy integration in the urban environment, specifically within the Greater Golden Horseshoe, and to ensure its viability and efficiency in the future by reviewing international best practices. 
Further, this paper will seek to refine the role of the municipal planner's toolkit to ensure that future development recognizes the benefits and strong role solar energy plays in meeting our greenhouse gas reduction targets, by answering the following questions:

1. What are the benefits to planning for solar energy?

2. How can solar energy play a stronger role in climate change adaptation and resiliency?

3. How can solar energy be better accommodated through provincial and municipal policies in the Greater Golden Horseshoe?

4. What are transferable lessons from international best practices of solar-friendly initiatives that could improve solar energy uptake in Ontario's planning process in the short, medium and long-term? 


\section{Research Background}

\subsection{What is Solar Energy?}

\subsubsection{Role of Solar Energy}

Solar energy is the most abundant and renewable source of energy on Earth. The quantity of solar energy that reaches the earth in just 1 hour is enough to power the entire world for a year (IPCC, 2011). With advancements in technology, solar power has the potential to contribute up to $16 \%$ of the global electricity mix in 2050 , making it the largest proportion of electricity being produced (IPCC, 2011; IEA, 2014). In Canada, the Canadian Solar Industries Association (CanSIA) projects that by 2020 solar sources could contribute 1\% of Canada's electricity generation (CanSIA, 2014), with a significant portion being generated in Ontario. Solar power is recognized as one of the solutions for achieving the "single largest climate change initiative in North America, reducing greenhouse gas emissions and air pollution" by phasing out coal-powered energy (Ontario Ministry of Energy, 2013). Over the last couple of years, solar energy has emerged in the climate change dialogue as a viable solution to curbing greenhouse gases and mitigating disasters (American Planning Association, 2015; Solangi et al., 2012; IEA, 2014). Further, the solar industry has the potential to provide 65,000 green-collar jobs (CanSIA, 2014). 


\subsubsection{How Does Solar Energy Work?}

Solar energy can either be harnessed actively through devices or be derived passively from design that facilitates energy efficiency and solar maximization. Typically, active solar energy technologies in an urban context involve mounting solar photovoltaic cells on the ground, on rooftops or onto buildings. Building materials can also have photovoltaic properties, these are known as building-integrated-photovoltaics (BIPV). Similarly, solar thermal energy technologies such as solar water heating collectors can also be integrated into the building materials and are known as building-integrated solar thermal (BIST). Photovoltaic panels harness electricity and either power the building or feed it into the grid network. Alternatively, solar thermal technologies use the captured heat for ventilation, domestic hot water and other heating purposes. Contrastingly, passive energy is a proactive approach to energy reduction, whereby the building is designed in such a way as to maximize solar heat and light gains. In either case, the quantity of solar potential of an area, otherwise known as insolation, dictates the viability of using solar energy in that area. Generally insolation depends on the time of day and season, atmospheric conditions, latitude and topography of an area (APA, 2014). On the site scale, several factors such as orientation, glazing ratios, building envelope characteristics, material selection, ventilation and roof pitch affect solar potential (APA, 2014; DeKay, 2012;

IPCC, 2011; Vandevyvere \&Stremke, 2012; Van Esch, Looman \& Bruin-Hordijk, 2012). 
The combination of passive solar design principles and active solar energy are main strategies for achieving a zero net energy consumption building, also known as net-zero building or a nearly net-zero building in some cases. In both passive and active solar energy cases, the built form, streetscape and vegetation influence the quantity and quality of energy gains from solar exposure (Hachem, Athienitis \& Fazio, 2010). Building orientation alone, for example, can improve electricity generation by as much as $50 \%$ depending on the configuration of the buildings compared to traditional built form (Hachem, Athienitis \& Fazio, 2010).

\subsection{Benefits of Solar Energy}

\subsubsection{Environmental Impact}

First and foremost, solar energy is renewable and abundant. There are fewer negative environmental impacts from solar energy than from traditional energy sources, including lower requirements for water (Environment Canada, 2012; IPCC, 2011). The disposal process of solar energy technologies is underway, whereby recycling facilities are being developed to properly dispose of solar panels and recycle heavy metals such as cadmium (Environment Canada 2012). 


\subsubsection{Economics}

The price of solar energy technologies has dropped significantly since 2010. At the same time lithium-ion batteries are becoming more affordable, meaning that on-site storage systems that are disconnected from the grid could be possible (IRENA, 2014). From 2010- 2014, the "levelized cost of electricity for solar PV has decreased by half" internationally (IRENA, 2014). Furthermore, the cost does not reflect the indirect benefits that solar energy provides such as peak shaving and reduced greenhouse gas production (Timilsina, et al., 2012; CanSIA, 2014). Several subsidies, as outlined in Section 2.3.3, alleviate the additional cost burdens of solar energy in Canada.

Passive energy design can improve the comfort level of the building and can save energy up to $15-40 \%$, depending on the age of the building (IPCC, 2011). BIPV and BIST can also allow for significant cost reductions if they are used in lieu of other materials (e.g. shingles, windows, exterior cladding) (Temby et al., 2014).

Decentralized energy production is also transforming the utility and consumers' relationship into a "democratic" relationship (IRENA, 2014) whereby anyone with access to a suitable property can generate their own electricity; making them a 'prosumer'. This 'distributed energy' is redefining the role of utilities and the need for transmission lines (Solangi et al., 
2012). Some prosumers may have the option of producing enough energy to disconnect entirely from the grid or feed any surplus back into the system.

\subsubsection{Local Autonomy}

Solar energy production may help alleviate our demand on centralized energy systems due to its proximity to the consumption source and the short installation time (IPCC, 2011). This is especially important in light of increasing infrastructural needs and in times when the grid is disabled. Another benefit of solar energy in the Ontario context is that its peak energy production coincides with the time the province's grid is in highest demand and therefore most vulnerable to power outages during the summer (e.g. mostly due to air conditioner use) (IPCC, 2011; Ontario Ministry of Energy, 2014).

\subsubsection{Versatility}

In general, the exact suite of solar technologies that are viable in an area depends on the maturity of the technology, its applicability to the local conditions and government policies (IPCC, 2011). Solar power is versatile both in terms of suitable land uses and scale. 


\subsubsection{Different Scales}

Solar energy can also be integrated into design at various scales. Vandevyvere and Stremke (2012) describe three major scales for energy generation as: macro, meso and micro scale. At the macro scale, energy is produced in order to significantly contribute to the regional energy mix through large-scale concentrated solar power plants and solar parks. The mesoscale reflects district/neighbourhood applications, where clusters of buildings receive their energy through small to medium sized solar fields or mid-scale solar applications, including asphalt collectors (Vandyvere \& Stremke, 2012). The micro-scale is focused on an individual building scale that incorporates passive and active solar design features to reduce energy demands.

From a land use planning perspective, planners plays an integral role at the meso and micro scales, as the feasibility and efficiency of solar energy relies heavily on the relationship to its surroundings through orientation and form of the built environment (APA, 2014; Hachem, Athienitis \& Fazio, 2010; Kanters \& Horvat, 2012; POLIS, 2012; Vandevyvere \& Stremke 2012; Van Esch, Looman, \& de Bruin-Hordijk 2012). 


\subsubsection{Suitable Land Uses}

Solar energy can be integrated into most land uses due to its size and versatility.

Various types of infrastructure can integrate passive solar energy principles and/or active solar energy technology to minimize energy requirements. Active solar energy can be incorporated through rooftop, building integrated or ground-mounted installations. Another benefit of active solar installations is that they can be used in conjunction with other land uses (APA, 2014;

Environment Canada, 2012) such as agriculture, positioned above parking lots to charge electric vehicles, or as an interim use on former industrial sites known as brownfields (APA, 2013; APA, 2014). Solar power can be a viable source of revenue generation as an interim use to address large lot vacancies such as industrial sites or strip malls given the photovoltaic panels' expected functional life of 25 years (APA, 2013). In other words, solar energy can be an ancillary use to a wide range of project development.

\subsection{How Does Planning for Solar Energy Work in Ontario?}

\subsubsection{Stakeholders Involved}

For solar energy projects at the meso and micro scale to be successful, many stakeholders, ranging from industry to academics and non-governmental organizations, have to be engaged. Beyond providing financial support, the public sector can play a key role in 
identifying unintended barriers to solar energy in regulations, addressing liability and acting as facilitators for bringing stakeholders together (APA, 2013). The American Planning Association recognizes the need for governmental actors that must also ensure that mechanisms are in place to account for the whole lifecycle of solar energy, including decommissioning, inspections and quality compliance enforcement (APA, 2013). External drivers, such as gaining international recognition, can be a motivator to municipalities to achieving sustainability planning (Gore \& Robinson, 2009).

\subsubsection{Role of Public Sector Planners}

In Canada, the planner's role is to assess and balance different priorities through policy and land use designation and justifications, while "integrat[ing] the needs of future generations" into planning practice (Canadian Institute of Planners, 2014). Godschalk and Anderson state that planners are uniquely positioned to engage community members, all the while developing and working with a suite of regulatory and policy tools that inform land use decisions (APA, 2013). Moreover, the planner has several roles with regards to planning for solar energy: developing and reviewing policy that considers various priorities on a temporal and spatial scale, site planning and community engagement. As the public liaison, planners can engage 
stakeholders to consider solar energy in the creation of a unifying plan. A planner can also help address community concerns regarding solar energy potential in neighbourhoods as well as provide resources to prospective solar energy implementers (APA, 2014).

\subsubsection{How is Solar Energy Planned for in Urban Areas?}

\subsubsection{Policy Drivers for Solar Energy Planning in Ontario}

Ultimately the impetus to plan for solar energy use is driven by the overarching federal and provincial goals addressing greenhouse gas reduction and climate change adaptation. Out of these goals emerge energy efficiency and renewable energy promotion as viable options for reducing emissions and investing in climate change adaptation and mitigation plans in the face of unpredictable climatic changes.

The federal and provincial governments both have strategies in place to cut greenhouse gas emissions and to address climate change adaptation. The federal government has committed to decreasing its greenhouse gas emissions by $17 \%$ by 2020 , relative to 2005 levels, by supporting and promoting energy efficiency and the expansion of the renewable energy sector with the Copenhagen Accord (Environment Canada, 2013). The "Federal Sustainable

Strategy Development" states that Canada can meet its target by promoting clean technology to 
the major industrial and transportation sector emitters, can continue to invest in the energy efficiency and renewable power programs by providing standard improvement and research funding, offer incentives to businesses to use clean energy generation equipment and provide support for climate change adaptation work (Environment Canada, 2013).

Ontario launched the "Ontario Go Green Action Plan on Climate Change" with short-, medium- and long-term targets for reducing the Province's GHG production. In order to reach the target of $15 \%$ below the 1990 levels before the 2020 , Ontario committed to helping municipalities reduce their greenhouse gas emissions (OMOE, 2007). The energy sector, both in closing down coal plants and working with municipalities to cut their GHGs, would contribute a significant reduction toward achieving these targets. At the time, the government invested 150 million dollars towards energy-related programs including equipping 100,000 rooftops with solar power (OMOE, 2007). In 2011, Ontario launched its first “Climate ready: Ontario's Adaptation Strategy and Action Plan 2011 - 2014" as its action plan for climate change, however no energy specific actions were listed in this plan. 


\subsubsection{Solar Energy Planning in Ontario - Energy Planning}

Energy supply and demand in Canada is delegated to the provincial level under the

Constitution Act, 1867. The federal government oversees the inter-provincial and international transmission of energy as well as the management of energy resources located on federal lands.

The Ontario Ministry of Energy and its associated public agencies have traditionally been the sole overseers of energy planning. In 2009, the Ministry of Energy created the Green Economy and Green Energy Act to promote renewable energies and facilitate the creation of 50,000 green jobs. Currently the Province has published a revised "Long Term Energy Plan" that envisions all of Ontario's electricity needs to be offset through incentive programs and building standard improvements, to be met by 2032 (Ontario Ministry of Energy, 2013). Ontario seeks to achieve this energy feat in the absence of coal and without the construction of new nuclear power plants in the near future. In order to compensate for the decline of these fossil fuel-dependent or radioactive sources, renewable energies will be phased-in at a more ambitious rate and located closer to their usage destination. This will cut down on transmission and distribution energy losses (Ontario Ministry of Energy, 2013). The Ministry of Energy intends on achieving these goals by bolstering the Micro Feed-in Tariff program, exploring 
business opportunities for energy production inside and outside of the province and placing a larger emphasis on energy conservation (Ontario Ministry of Energy, 2013).

The Ministry of Energy encourages municipalities to think about energy issues through the creation of energy management plans. In terms of municipal operations, as of July 2014, the Ministry requires all public agencies to make five-year conservation demand management plans that are publically available and are renewed every five years. Public agencies include municipalities, municipal service boards, universities, colleges, school boards and hospitals (Ontario Ministry of Energy, 2015).

The Ministry of Energy encourages municipalities to develop community energy plans (CEPs) in order for them to identify their local energy needs, to determine opportunities for better energy efficiency (e.g. home energy retrofits), and to outline renewable energy solutions that satisfy these demands (Ontario Ministry of Energy, 2014). Currently there is no standard approach to creating community energy plans, and the municipality's ability to carry out the implementation of these actions varies significantly (Quality Urban Energy Systems of Tomorrow [QUEST], 2015).

Not all municipalities have community energy plans. Several address energy through integrated community sustainability plans (ICSPs). These long-term action plans integrate 
various environmental, cultural, social and economic targets for the municipality in line with the community's vision. An incentive for municipalities to develop ICSPS is that they become eligible for the Gas Tax Fund. This fund supports municipal infrastructure projects including community energy projects. Similar to CEPs, there are no clear guidelines on developing an ICSP, leaving municipalities to formulate and tailor their sustainability plan to meet their own needs. Some ICSPs include actions for energy. In the same vein as Community Energy Plans, Ling, Hanna and Dale (2009) claim that ICSPs can be improved by addressing: the absence of a clear framework for integration, inappropriate scale, governance structure not properly suited to realizing actions, the absence of an interdisciplinary approach between departments and insufficient public participation. Moreover, successful plans typically have institutionalized processes that bridge together community, technology and environment through a robust governance structures (Burch, 2010; Ling, Hanna \& Dale, 2009; Robinson, 2012). Sustainability plans have the advantage of approaching municipal priorities holistically and engaging various stakeholders. 


\subsubsection{Solar Energy Planning in Ontario - Urban Planning}

The dialogue on energy planning between the Ministry of Energy and municipalities is growing. Many of land use planning considerations directly impact the energy sector through built environment and density. Recognizing this emerging and complex relationship of energy planning in the municipal domain, Quality Urban Energy Systems of Tomorrow (QUEST) and the Canadian Urban Institute (CUI) developed a report on Integrated Community Energy Solutions (ICES) to highlight what regulatory tools municipalities have control over to enable renewable energy planning. According to Natural Resource Canada:

"ICES is an approach that offers holistic solutions for reducing GHG emissions and addressing climate change by evaluating how energy is supplied and consumed across sectors. ICES capitalizes on cross-cutting opportunities and synergies available at the community level by integrating physical components from multiple sectors, including energy supply and distribution; transportation; housing and buildings; industry; water, waste management and other local community services; and land use and community form." (QUEST \&CUI, 2010 p. 7).

The ICES approach helps orient the planner within the existing land use decision framework (Figure 1) to identify what the policy drivers are for achieving 'sustainable' compact communities that have the potential of being "energy conscious" (Vandevyvere \& Stremke, 2012). Planning for solar energy in urban areas requires a holistic approach for successful 
integration, as solar energy feasibility is directly affected by land use patterns. The following section expands the ICES municipal tools, as presented in land use planning in Ontario, and reviews them through the lens of planning for solar energy. Additional land use regulatory tools have been added to the ICES toolkit that have the potential for promoting solar integration in the built environment.

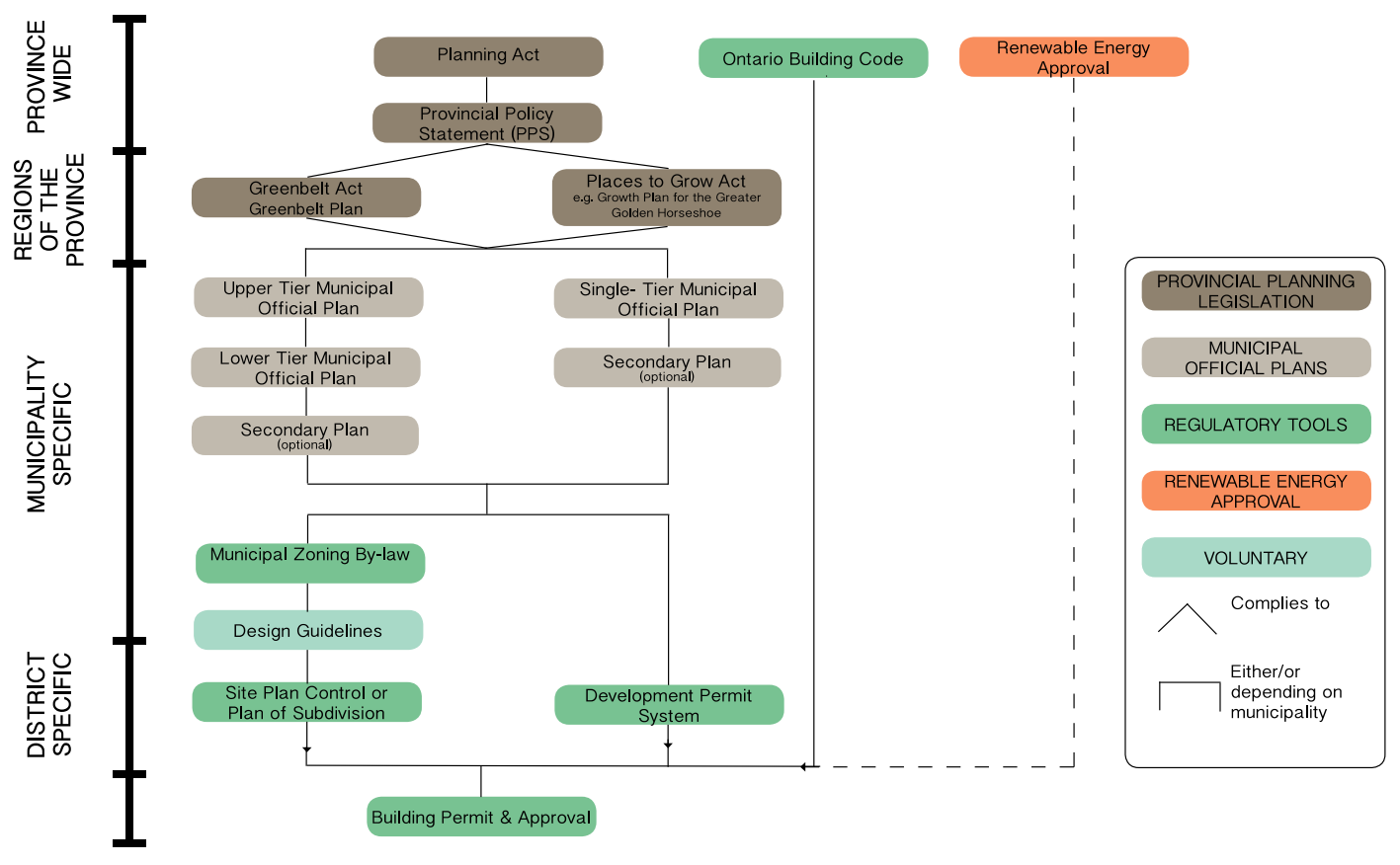

Figure 1 Land use planning in Ontario 


\subsection{Planning Act \& Provincial Policy Statement}

The Ontario Planning Act sets the legislative framework for land use planning, identifies matters of provincial interest and requires that all land use decisions be consistent with the Provincial Policy Statement. The Provincial Policy Statement (PPS) is the overarching policy that drives strategic land use planning and development in the province in order to "promot[e] strong, liveable, healthy and resilient communities, [protect] the environment and public health and safety, and facilitating economic growth" (Ontario Ministry of Municipal Affairs and Housing [OMMAH], 2014). Planners are mandated by the Provincial Policy Statement to "provide opportunities for the development of energy supply ... to accommodate current and projected needs" including promoting renewable energy systems (OMMAH, 2014, sect.1.6.11) in order to ensure long-term economic prosperity (OMMAH, 2014, sect. 1.7.1). Planning can also play a significant role in climate change adaptation and greenhouse gas emissions reduction by encouraging development patterns that could support both passive and active solar projects (OMMAH, 2014, sect. 1.8.1.f). 


\subsection{Regionally Specific Land Use Plans}

Intensification of the built form due to population pressures in designated urban growth centres is promoted by the protection of settlement area boundaries in the Greater Golden Horseshoe as outlined in the Greenbelt Act, 2005; Places to Grow Act, 2005; and their respective plans. These regional plans encourage compact community development in order to promote intensification in existing urban areas, brownfield redevelopment and transportation networks conducive to active and public transportation, all the while preserving natural and agricultural areas. These plans are updated every ten years.

\subsection{Municipal Plans \& Regulations}

An official plan (OP) is a comprehensive long-range plan that guides land use decisions in the municipality that are consistent with the Provincial Policy Statement. A two-tiered system or a single tier may govern municipalities. In the case of the two-tiered system, service provision is divided between the upper tier, which deals with broad planning issues, and the lower tier, whose responsibilities are focused on local issues (OMMAH, 2011). At the district scale, OPs may have additional policy specifications imposed in certain areas as identified in secondary plans. 
Official plans may specifically address energy efficiency and renewable energy projects (QUEST \& CUI, 2010). For example, in the draft official plan for the City of London, Ontario includes specific directives that promote passive solar energy and accommodate solar energy in neighbourhood designs (City of London Corporation, 2014b) (see Appendix A for City of London Corporation examples of solar energy considerations in the official plan draft). The London OP is further supported by the Community Energy Action Plan's local energy principles and priorities that promote energy efficiency and renewable energy generation (City of London Corporation, 2014a). This unprecedented approach to integrating solar energy into the Ontario official plans sets the stage for solar energy considerations in new developments in Ontario.

\section{Zoning By-Laws}

The zoning by-law (ZBL) is the regulatory tool that municipalities use to legally enforce the official plan. It designates the land use, types of building, and their corresponding building envelope (i.e. height, setbacks, etc.) for each parcel of land. 


\section{Plan of Subdivision/Site Control Plans}

At the neighbourhood level, official plans may have additional urban design

specifications imposed in certain area. These design standards are enforced through site

control or subdivision plans. For example, the site plan control could require sustainable design

features-such as solar energy, be integrated into the design before issuing a building permit.

\section{Development Permit System}

Alternatively to the zoning by-law and site plan/ subdivision control, the Planning Act also allows municipalities to regulate land use at a neighbourhood scale, through the Development Permit System. In this case, the Official Plan must clearly identify the boundaries of the regulated area and reflects the goals and objectives of the development permit by-law, identify the criteria by which development permit systems will be evaluated, state the design conditions that will be imposed and outline the role of the authority in enforcing the DPS (OMMAH, 2007). The DPS model bundles together the site plan control or subdivision plans with zoning and design guidelines. Solar energy considerations at the neighbourhood scale could be incorporated into the development permit during the visioning process that involves community members. However, currently only five municipalities have adopted the DPS as a 
tool in their municipalities (Lake of Bays, Carleton Place, Gananoque, Brampton and Toronto)

(City of Toronto, 2015), none of which have added specifications for solar energy.

\section{Height and Density Bonusing}

Under Section 37 of the Planning Act, developers may request a zoning amendment to increase the height and density of buildings in exchange for community benefits. Height and density bonusing could be an ICES tool by including clear bonusing policies that directs funding to specific community benefits, such as mixed-use communities in the OP (QUEST \& CUI, 2010).

\subsection{Renewable Energy Approval}

Renewable energy projects, such as ground-mounted solar projects with a capacity greater than $10 \mathrm{~kW}$ may require a renewable energy approval under the Environmental Protection Act to determine the impact on natural and cultural heritage (i.e. heritage- designated areas and natural areas). The municipality or province may alter or restrict certain types of solar integration on designated heritage sites. 


\subsection{Municipal Voluntary Initiatives}

\section{Sun/Shadow Study}

A sun/shadow study is an additional report municipalities may request prior to issuing

the building permit to determine the shadow impact of the new development on the surrounding public realm such as parks and streetscapes. These studies do not consider the impact of the shadow on surrounding existing and projected built form. In other words, the sun shadow study evaluates the length of time that the public realm is exposed to daylight. It does not factor in how future buildings, as per the required zoning or even exempted zoning, would interact with one another.

\section{Energy Mapping}

In 2011, a collaborative project was undertaken by the Canadian Urban Institute, Ontario Power Authority, CanmetEnergy of Natural Resources Canada, the Ontario Centres of Excellence, participating municipalities and local distribution companies to develop the integrated energy mapping for Ontario communities (IEMOC) tool (CUI, 2011). The purpose of this tool was to visually demonstrate energy demands spatially across the municipality as well as factor in future building projections in order to identify strategic opportunities for energy 
reduction (CUI, 2011). Opportunities for energy reduction included identifying areas of highenergy demand that can be alternatively powered by renewable energy.

\section{Other Voluntary Initiatives and Targets}

Several additional incentives are promoting solar integration at various scales, one being the Leadership in Energy \& Environmental Design (LEED) green building certification that allows builders to earn points towards the sustainable building designation for renewable energy integration into the design. Similarly, the Toronto Green Standards provides an additional incentive to developers by waving development charges if they meet the second tier criteria which includes the use of "on-site renewable energy technologies to supply at least $5 \%$ of the building's total energy use from any one source (e.g. natural gas or electricity)" (City of Toronto, 2010).

\subsubsection{Implications of GEA on Planning}

In addition to amending the Building Code to set energy conservation provisions for design, the GEA amended the Planning Act whereby neither municipal official plans nor municipal zoning by-laws can restrict renewable energy undertakings such as solar energy 
(Green Energy Act, S.O. 2009, Schedule K). Furthermore, restrictions on appellant powers were imposed where only projects that are deemed to cause "serious harm to human health or serious and irreversible harm to plant life, animal life or the natural environment" (Environmental Protection Act, R.S.O. 1990, note 6, section 18) can be appealed.

\section{Appeal Bodies}

In the event that a party wishes to appeal a municipal decision, plan or policy that is not exempt under the GEA, the Planning Act permits parties to present a case to the Ontario Municipal Board (OMB). Following a hearing, the OMB makes a decision based on the local context and provincial planning goals. The OMB is meant to provide oversight and ensure that planning decisions reflect provincial priorities.

\subsubsection{Available Funding for Solar Energy Projects}

As part of the federal and provincial mandate to prioritize greenhouse gas reduction, energy conservation and climate change and adaption, various funding streams are available. Furthermore, in light of the fact that financing is a major barrier to solar energy deployment, all tiers of government have addressed this issue by providing various forms of incentives and 
sustained financing to individuals, businesses and local governments actively implementing solar technologies into buildings. Ontario has distinguished itself internationally as a promoter of renewable energy through the Feed-In-Tariff program (Solangi, et al., 2011; Desmuhk et al., 2011). Other financial programs are available from both the public sector as well as private and coop sectors as outlined below, such as tax breaks, low interest loans and grants.

\subsubsection{Federal Funding}

The federal government provides funding for solar energy indirectly through multiple streams. The following section will highlight the major financial support programs to the private and public sector in solar energy implementation projects.

\section{Accelerated depreciation}

Under the Income Tax Regulations, renewable energy producers, including those

producing solar energy, are eligible for accelerated capital cost allowance. A percentage of eligible equipment can either be written off as long as it has been acquired between 2005 and 
2020. The federal government provides the producer with several options for deducting capital costs (Natural Resources Canada [NRCan], 2014).

\section{Funding for Municipal Projects}

Municipalities can apply for several federal grant-funding programs. The Green Infrastructure Grant is part of “Canada's Economic Action Plan" (2009-2014) for projects targeting greenhouse gas emissions reduction, clean air and clean water (Infrastructure Canada, 2014). The funding is provided on a cost-sharing basis either to partnerships or single applicants. Only two projects have been funded in the energy sector, neither of which comprised solar energy ventures. Another available funding source for energy projects for municipalities is the Green Municipal Fund (GMF) managed by the Federation of Canadian Municipalities (FCM). In order to be eligible for funding, the municipality must have a Municipal Sustainable Community Plan or Strategy (see 2.3.3) already developed. The City of Halifax has successfully received a one-time grant to provide the start-up capital for its Solar Hot Water project (FCM, 2015).

The federal Gas Tax Fund administered by the Association of Municipalities of Ontario and the City of Toronto fund municipal infrastructure projects or sustainability plans. 
Municipalities can use these funds for a wide range of projects including CEPs or community energy systems. Several communities such as Ajax, Brockville, Ramara and Wawa in Ontario received partial funding from the Gas Tax Fund to install solar panels on their municipal buildings (Infrastructure Canada, 2012a, 2012b, 2013, 2014).

\subsubsection{Provincial Funding}

The GEA introduced several funding programs and launched incentives adding to the suite of tools municipalities have to promote solar energy integration. The following section outlines funding options available provincially for the neighbourhood and building scale.

\section{Neighbourhood scale}

\section{Local improvement charges}

A local improvement charge (LIC) is a tool municipalities use to finance infrastructural

projects in a certain area. Residents living within a pre-set vicinity of this infrastructural project providing an improvement to the community have a special charge added to their property tax bill. In 2012, the Ontario Ministry of Municipal Affairs and Housing allowed the amendment of the O.Regs. 586/06 and 596/06 under the Municipal Act, 2001 and the City of Toronto Act, 2006, respectively, to permit private properties to benefit from Local Improvement Charges 
(LICs). This means that property owners can pay back a loan to the municipality through this added fee on their property tax bill for energy efficiency upgrades and solar panel installations.

Risk of capital investments losses is lessened as the loan is attached to the property rather than the owner (QUEST \&CUI, 2010).

\section{Community improvement plans (CIP)}

Under Section 28 of the Planning Act, municipalities can designate certain areas as "community improvement plan project area" in their official plan (OMMAH, 2010). These areas typically address maintenance and redevelopment and can include design guidelines such as solar energy. Municipalities support these projects with earmarked funds.

\section{Building scale}

\section{Feed-in-tariff \& MicroFit}

Amendments to the Green Energy and Green Economy Act, 2009, allow for Ontario renewable energy producers to enter into a contract with the Independent Electricity System Operator (IESO) for up to 20 years. The Feed-in-tariff (FIT) program is geared towards electricity producers that are between $10-500 \mathrm{~kW}$ whereas the microFIT program primarily targets households capable of generating a surplus of 10 kilowatts or less of energy on their 
property to be fed into the grid network. The property owner enters into a 20-year contract, depending on the energy source, for all the electricity produced (IESO, 2015). Rooftop microFit installations do not affect the property assessment value (OMOE, 2012). Solar thermal projects are not currently eligible in the Micro-FIT program.

\section{Provincial green bonds}

Launched in October 2014, the Ontario government now offers bonds specific to funding sustainability projects to municipalities. These green bonds can be used toward energy efficiency and conservation projects; clean energy and technology projects, and climate adaptation and resilience projects among other categories (Ontario Financing Authority, 2014).

The Financing Authority staff in consultation with the Province's Green Bond Advisory Panel decides which projects receive this bond option. Both private and public sector investors are eligible for these bonds. Benefits of the Green Bonds include: providing funding specifically to projects that will reduce greenhouse gas emissions, providing funding for long-term projects that are not vulnerable to political short term agendas, contributing to the green job economy by bolstering their financing, funding needed infrastructure upgrades and fulfilling the growing desire of citizens of wanting to invest in ethical and environmentally-focused projects (Lanz, 2014). 


\section{Net-metering}

Net-metering is a separate program from the microFIT and FIT program where the distribution system credits renewable energy producers for feeding the grid electricity. The amount of surplus energy generated to the grid is deducted from the producer's electricity bill and cannot exceed 500 kilowatts (Ontario Energy Board, 2014).

\subsubsection{Alternative funding models}

Third party ownership, such as through co-ops, are becoming popular means for funding solar energy projects. SolarShare, for example, is a cooperative that invests in solar energy across Ontario. SolarShare is part of the TREC Toronto Renewable Energy Co-op that gains its profits through the FIT program. Investors seeking "green" projects have been attracted to this model (SolarShare, n.d.). 


\subsection{Why Study Solar Energy in Urban Planning?}

\subsubsection{Hot Topic}

The solar energy agenda is growing as it gains more recognition as a key part of reducing greenhouse gas emissions in the building sector and in contributing to energy security during disaster periods due to its distributive properties (Newton and Newman, 2013). Solar energy has only recently gained a lot of public interest. This is because, since 2010, solar PV uptake increased by $360 \%$ from $39 \mathrm{GW}$ to more than $179 \mathrm{GW}$ as prices dropped by $75 \%$ of 2009 rates (IRENA, 2014). Several American states have reached or are approaching grid parity for solar energy, where the cost of on-site generation is equivalent in cost to buying it from the distributor (Rocky Mountain Institute [RMI], Homer Energy \& Cohnreznick Think Energy, 2015).

The energy sector will have to address the disruptive effects of solar power on the utility companies' revenue stream as it will fundamentally affect their revenue stream (RMI, Homer Energy \& Cohnreznick Think Energy, 2015). The impacts of decentralized energy production and the increasing off-grid capabilities of buildings through storage will reduce the need for energy supplied from centralized stations. Solar energy potential is set to continue capturing mainstream attention as advancements in technology, efficiency, storage and versatility in integration further improve. 
Taken in an Ontario context, the province anticipates generating $2 \%$ of its energy from active solar energy by 2032 (Ontario Ministry of Energy, 2013). Passive solar energy will also contribute to reducing energy requirements.

\subsubsection{Lots of Interest}

Arguably, much attention has already focused on designing the current and future building stock more energy-efficiently on the individual building scale (IPCC, 2011). Academics have also conducted jurisdictional scans of best policy practice for solar energy integration. However, the academic focus has primarily been on economic drivers. In Desmukh et al.'s international economics scan, he separates necessary financing policies for solar promotion into two overarching groups: "push" and "pull" policies. "Push" policies are directed at improving the technology to make it viable in the market, by investing in research, development \& demonstration (RD \&D) through grants and supporting the manufacturing industry through training programs, subsidies and tax concessions, (Desmukh et al., 2011). "Pull” policies focus increasing the demand for solar energy through increasing generation capacity. Both the Renewable Portfolio Standards and the Feed-in-tariff are examples of pull policies (Deshmukh et al., 2011). Solangi et al. conclude that pull policies such as the Feed-in-tariff are the best 
drivers of solar energy implementation (2011). Timilisina et al. provides a broader study lens by analyzing solar market trends in relation to economical, technological and institutional barriers.

Researchers conclude that a tailored combination of push and pull strategies are needed for successful deployment.

More research is needed to address: reliability of intermittent energy sources such as through storage and improving conversion efficiencies of PV modules (Timilsina, et al., 2012), sufficient supply of raw materials for PV production (Timilsina, et al., 2012), reduction of air pollutants produced during manufacturing (Environment Canada, 2012) and safe disposal of batteries (Timilsina, et al., 2012). Furthermore, specific standards are needed to ensure the building code is compatible with upcoming solar energy technologies (Timilsina et al., 2012) and for performance and monitoring such as for BIPV (Temby et al., 2014; Environment Canada, 2012). Successful international solar deployment strategies have benefitted from national and international networks that allows experts to share ideas and 'cross-pollinate,' resulting in capacity building and the advancement of the industry (Deshmuhk et al., 2011; Timilisina et al., 2012).

Legal channels have also been explored for promoting and protecting the solar energy resource, in other words, legal right for access to insolation. In Gibson's Solar Access Report to 
the city of Toronto he uses Kruhlak's legal definition of 'right to light' to mean: "a legally enforceable right to a reasonable proportion of the natural unobstructed flow of direct solar radiation" (Gibson, 2014). The notion of 'right to light' dates back to England in the 1600 s and was incorporated into common law in Canada in the 1800s. In an attempt to reduce barriers to construction, the law was eventually overturned in all provinces. However a resurging interest in this law has occurred in the last ten years. In 1978, California set the stage for solar rights by enacting the Solar Rights Act and Solar Shade Control Act, requiring property owners to enter into an agreement to prevent obstructions to solar access as per the California Civil Code (Law Reform Commission of Saskatchewan, 2007). In 2007 the Saskatchewan environment minister commissioned a review of the right to light recognizing the growing integration of solar energy technology on new buildings and exploring appropriate laws for solar protection (Law Reform Commission of Saskatchewan, 2007).

Legal issues surrounding solar access have been an issue in Ontario. Gibson found two Ontario Municipal Board cases in Toronto. The first was an appeal to the Minto development at Yonge and Eglinton in 2002 by surrounding residents claiming that the high rise would increase shading on their property. Gibson's research revealed that the City Planning Staff report required a reduction in the height the Yonge- Eglinton Minto buildings due to shadow impact on 
the surrounding low-density area (2014). Although the appellants were unsuccessful in preventing the construction, Gibson notes that the City was able to enforce a height reduction. Another Toronto case regarding the construction of the Art Gallery of Ontario construction was appealed due to concerns with reduced solar access to a homeowner's solar panels. Little information is available as the case was settled before the hearing (Gibson, 2014).

\subsubsection{The Early Days for Solar Energy in Urban Planning}

Planners are tasked with developing policies that integrate and reflect the values and resource potential of our social, economic and environmental capital. The question becomes how to facilitate a community of these buildings that synergistically fulfill their buildings' function and meet the needs of the users without obstructing each other. Planners play a key role in addressing this issue, as spatial planning greatly influences building performance (Vandevyvere \& Stremke, 2012), thereby compelling planners to think of the energy beyond the building footprint (Vandevyvere \& Stremke, 2012). Without clear action plans for solar deployment, future development projects can jeopardize access to light of buildings utilizing solar energy. Yet little academic research discusses the conflict between these sustainability goals such as compact communities and solar energy production (Hamin \& Gurran, 2009). Recognizing the 
integral role that the surrounding built form plays on ensuring the efficiency and viability of solar energy, the International Energy Agency formed the Task 51: Solar Energy in Urban Planning in 2013 to identify barriers in the planning process and develop tools and policy recommendations to address these issues. Preliminary research conducted by a Canadian Task 51 member Haines in 2014 involved interviewing experts in the solar field. A major barrier highlighted by the expert interviews in the Greater Toronto Area was that planners and developers lack the skills and awareness to plan for energy (Haines, 2014). The International City/County Management Association (ICMA) also observed the planner of solar energy literacy in 2011 when they conducted a study to understand why solar energy is not more prevalent in planning in the United States (APA, 2013).

\subsubsection{Identifying a Need to Study Solar Energy in Urban Planning}

Traditionally, energy planning has been relegated to engineers and sciences within the Ministry of Energy, under the guise of it being a technical issue whereas land use planning occurs at the municipal level by planners, policy makers and politicians. Given the impact land use planning decisions on solar energy; however, it is evident that a stronger dialogue between land use and energy planning is required especially in light of urbanization trends. 
Currently, planning operations are not required to consider solar potential, making planning in essence 'solar agnostic.' As a result, urban planners develop policies and design communities without fully considering the impacted potential of each building to capture solar energy. A possible reason why land use planning has lagged in relation to other sectors (e.g. financing and research and development) may be due in part to the GEA amendments. Several people in the municipal planning realm deduce that the exemptions from municipal regulations for renewable energy projects removes the municipality's ability to wave regulations in order to incentivize RE projects (Manning \& Vince, 2010; QUEST \& CUI, 2010).

The consequences of this 'solar agnostic' phenomenon is only starting to be evidenced in literature. The American Planning Association predicts "as solar development becomes more commonplace, conflicts and concerns about how and where development occurs are likely to become more prevalent" (APA, 2014, p. 28). The international community is starting to experience this phenomenon. Australia, for example, is experiencing an increased level of appeals regarding building permits that are obstructing their solar access (Newman \& Newton, 2013). Good, Lobaccaro and Harklau (2014) found that the irradiation of building in Trondheim Norway with BIPV was reduced by $28 \%$ when the adjacent parcel was built on. Lobaccaro and Frontini (2014) build on this conversation by questioning the abundance of solar energy if the 
built form is not designed with to accommodate solar potential considerations. Gibson (2014) adds to this dialogue within a Toronto context by noting that the City is the leader in tall building construction in North and without solar considerations, the projected 80-storey Gehry buildings will likely impact the irradiation potential of the surrounding midrise development (Gibson, 2014). In addition to the surround built form, municipal policies can also conflict with solar energy applications, such as the promotion of green rooftops that takes away from prime solar real estate (Kanter \& Horvat, 2012). This last point is especially important in the City of Toronto where a green-roof by-law requires all new buildings be constructed with the green-roof feature.

The American Planning Association (2014) identifies the following municipal priorities as potential for conflicts with solar energy potential:

- Tree protection and urban forestry goals

- Historic and heritage preservation goals

- Urban redevelopment - intensification

In Ontario, these priorities are defined in the Provincial Policy Statement (OMMAH, 2014).

Green infrastructure: means natural and human- made elements that provide ecological and hydrological functions and processes. Green infrastructure can include components such as natural heritage features and systems, ..., street trees, urban forests, ..., permeable surfaces, and green roofs. 
Heritage attributes: means the principal features or elements that contribute to a protected heritage property's cultural heritage value or interest, and may include the property's built or manufactured elements, as well as natural landforms, vegetation, water features, and its visual setting (including significant views or vistas to or from a protected heritage property).

Intensification: means the development of a property, site or area at a higher density than currently exists through:

a) redevelopment, including the reuse of brownfield sites;

b) the development of vacant and/or underutilized lots within previously developed areas;

c) infill development; and

d) the expansion or conversion of existing buildings.

Identifying conflicting priorities prior to the plan development can help ensure the success of solar energy integration in the long run (APA, 2013). A proactive approach to planning for solar energy can also avoid conflicts in the long-term. The American Planning Association provides municipalities with several opportunities for 'solar' intervention in policy planning. Given that municipalities in Canada are 'creatures of the province' and that all official plans must comply with the Provincial Policy Statement, these interventions can also be considered for the provincial policies and regulations. The five strategic interventions are summarized below:

Visioning and Goal Setting: This is the first opportunity to engage the community in the making of plans in order to develop a vision for the community. The planner facilitates this 
public engagement by helping to identify key values and goals for the community. The APA identifies this as the first strategic point of intervention for promoting solar energy. Having solar energy integrated into the vision of the community will guide all future municipal land use decisions (APA, 2014).

Plan Making: This second intervention speaks to integrating solar energy into local plans, as these are the 'road maps' that dictate decision making, regulations and programs. Plans can lay out how municipalities will address safety and liability concerns for the maintenance enforcement and proper decommissioning of these technologies (APA, 2014).

Regulations and Incentives: The third intervention requires planners to review municipal planning tools such as zoning, site plan controls and the development permit system (in the Ontario context) to identify and reassess any intentional or unintentional barriers to solar energy.

Development Work: The fourth intervention refers to the role of private partners in engaging in solar energy deployment. This means considering the importance of publicprivate partnerships in solar deployment. A clear understanding of the role of private 
partners can help municipalities tailor their review process and incentive programs to promote solar integration.

Public Investment: The fifth intervention refers to public investment to promote solar energy. Public investment refers to municipalities' deployment of solar technology on their infrastructure. This allows municipalities to lead by example. 


\section{Methodology}

\subsection{Problem Setting}

This exploratory major research paper will provide recommendations for promoting and supporting solar energy in Ontario's planning process in light of the unique policy review window of the Greenbelt Plan and the Greater Golden Horseshoe Plan. Using an integrative review (Newman, 2011) approach, this paper will highlight the current state of solar energy as portrayed in the available peer-reviewed literature, identify research gaps and demonstrate how it relates to land use planning.

The purpose of this paper is to contribute to the solar energy dialogue in relation to planning in Ontario, by making a case for why planners must be involved in solar energy integration. This research is the result of a multi-method process by building on the qualitative interviews conducted by Haines in 2013-2014 for the Task 51. These interviews provided expert perceptions of the opportunities and challenges of solar energy uptake in the City of Toronto.

In light of Haines' work, the first stage of this research involves a thorough familiarization of the current provincial land use and energy planning practices to understand how these processes interact and identify the synergies and deficits. Based on the literature, the following questions emerged: 
1. What are the benefits to planning with solar energy?

2. How can solar energy play a stronger role in climate change adaptation and resiliency?

3. How can solar energy be better accommodated through provincial and municipal policies in the Greater Golden Horseshoe?

4. What are transferable lessons from international best practices of solar-friendly initiatives that could improve solar energy uptake in Ontario's planning process in the short, medium and long-term?

\subsection{Methods}

\subsubsection{Current Status of Planning for Solar Energy in Ontario}

The first part of this major research involved understanding what solar energy is, its benefits and challenges, the incentives available and how the current planning process in Ontario enables its integration into society/municipalities. In order to identify opportunities for promoting solar energy in Ontario's Greater Golden Horseshoe through land use planning, an analysis of the provincial plans was conducted to identify priorities that may conflict with solar energy integration. Special attention was given to green infrastructure, heritage attributes and 
intensification as identified as potential conflicting priorities by the American Planning Association.

\subsubsection{Current International Best Practice Review}

To develop a sound understanding of how Ontario's solar energy planning compares to other systems abroad and to deepen an understanding of progressive and effective initiatives elsewhere, an academic and grey literature review was conducted. Secondary sources including non-governmental organizations, government and industry papers were consulted. This background research helped identify best practices and leaders in solar energy implementation. The purpose of reviewing these international cases was to extrapolate general themes representing the drivers of solar energy integration. These themes were: addressing intensification pressures by using marginal lands from (1) transportation infrastructure and (2) brownfields, (3) solar energy as a contributing factor to establishing international reputations as solar cities, (4) integrating solar energy mapping into resilience planning and (5) incorporating solar energy into climate change mitigation plans. This analysis involved examining a range of different land use projects (i.e. site specific, greenfield, infill brownfield, adaptive reuse, neighbourhood, precinct, rural, transportation corridors). The case studies were selected based 
on the convenient sampling method (Newman, 2011), using projects that have recently gained media attention, that are award-winning sustainable communities and that were informed by the International Energy Agency Task 51: Solar Energy in Urban Planning experts conferences. General information including date of project development, location, land use, anticipated population, financing, actors, goals and supporting plans and policies were entered into "partially ordered meta-matrix" (Miles, Huberman \& Saldaña, 2013) in order to highlight key themes and relevant transferable opportunities from these examples. Completing the matrix was an iterative process involving discussions, reflections and reformatting. Once the chart was filled out, the information was partitioned and clustered into common themes (Miles, Huberman \& Saldaña, 2013) for transferable lessons based on the five strategic interventions for Ontario's context over the short, medium and long-term horizons. The time horizons were selected to reflect what is feasible in the short-term within the current legislative system, what could be possible given some changes to the policy (medium-term) and what would not work in Ontario in the near future but serves as an interesting case study and possibly as a model for best case scenario (long-term). 


\subsubsection{Analysis and Recommendations Formulation}

Based on the literature review and case analysis, key themes and conclusions were identified to address the research questions. Recommendations were formulated for the province and generally for municipalities based on the five strategic points for intervention as listed in section 2.4.4.

\subsection{Limitations}

This major research paper seeks to address only issues regarding solar energy planning in urban areas. The scope was limited to urban areas as planners as the design of the built form highly affects solar energy efficiency. The majority of this research was compiled from secondary sources based on the most current information available. Solar energy is an emerging field that has recently captured the international community's attention. As a result, information is being published and disseminated daily (ranging from academia, to industry, to television/the public level). Due to time constraints, the information reviewed was selectively chosen representing large organizations and leading solar energy countries research. In addition, given the speed at which the solar energy technology is developing and improving, it is likely that the provincial policy recommendations provided will have to be re-evaluated on a 
frequent basis to ensure they reflect best industry practice. Another limitation in the quality of this report is that most of the accessible information on solar energy and planning is provided from industry and government sectors. The Task 51 experts conferences and the SunShot Solar Outreach Partnership website were the significant sources of information for this research. Neither the Canadian Planning Institute, the Ontario Professional Planning Institute nor the Federation of Canadian Municipalities have any resources on solar energy. 


\section{Problem Investigation}

All pertinent provincial land use-planning considerations are identified below in order to highlight conflicting policies both within documents and between documents regarding urban canopy, historic preservation, intensification and solar energy. Explained within each section are the regulatory tools that municipalities may employ to comply with the provincial legislation.

\subsection{Priorities from the Provincial Policy Statement}

Planners are mandated by the Provincial Policy Statement to "provide opportunities for the development of energy supply ... to accommodate current and projected needs" including promoting renewable energy systems (OMMAH 2014, sect. 1.6.11) to ensure long-term economic prosperity (OMMAH, 2014, sect. 1.7.1). Planning can also play a significant role in climate change adaptation and greenhouse gas emissions reduction by:

"promoting design and orientation which: maximizes energy efficiency and conservation, and considers the mitigating effects of vegetation and; maximizes opportunities for the use of renewable energy systems and alternative energy systems" (OMMAH, 2014, sect.

\subsection{1.f.)}


Within the same mandate; however, the PPS, 2014 also requires planners to reduce greenhouse gas emissions by intensifying the built form by "promot[ing] compact form" (OMMAH, 2014, sect. 1.8.1 a) and "maximiz[ing] vegetation within settlement areas" (OMMAH, 2014, sect. $1.8 .1 \mathrm{~g}$ ). Heritage is also addressed in the PPS by ensuring that "Significant built heritage resources and significant cultural heritage landscapes shall be conserved" (OMMAH, 2014, sect. 2.6.1). Clear direction on how to address these priorities synergistically would avoid pitting one priority over the other.

\subsubsection{Green Infrastructure}

Green infrastructure is a common action of Integrated Community Sustainability Plans.

Municipalities can set urban canopy standards in order to promote and protect vegetation growth inside their jurisdiction. The Municipal Act also permits municipalities to "prohibit or regulate the destruction or injuring of trees" (Municipal Act, c. 32, Sched. A s. 71). The tree bylaw protects trees from removal for the purpose of renewable energy projects. 


\subsubsection{Heritage}

Heritage sites are protected if they have design, physical, historical or associative value

(Heritage Act, O. Reg 9/06) under the Heritage Act. This act allows municipal or provincial bodies to delay or stop demolition of heritage sites and provide standards and guidelines for the preservation of these sites. Heritage designations may be applied to individual sites or to clusters of buildings in a given geographic zone. The severity of these standards and guidelines applied to these heritage designations vary between and within municipalities. In order to move forward with a renewable energy project, authorization from the appropriate party is required. Modifications to the proposal may be imposed to ensure the integrity of the heritage building to ensure that it does not compromise the integrity of the site's character.

\subsubsection{Intensification}

Intensification is promoted by the protection of settlement boundary plans as discussed in the regional plans section above. Within the same GGH plan, policies 2.2.3 require that a minimum of $40 \%$ of all new development must take place in already built up areas. Energy efficiency is promoted through land-use patterns and urban design standards that "encourage and support energy-efficient buildings" in policy 4.2.4.iv (Ministry of Infrastructure, 2006). The GGH plan also recognizes the necessity of energy conservation on a municipal scale by 
1. identif[ying] opportunities for alternative energy generation and distribution[...]

3.[developing] land-use patterns and urban design standards that encourage and support energy-efficient buildings and opportunities for cogeneration.(OMMAH, 2006, sect. 4.2.4.2)

To promote brownfield redevelopment in urban areas, municipalities may use community

improvement plans as described in section 2.3.3 of the GPGGH, 2006. These plans could have clauses that specify energy requirements (QUEST \& CUI, 2010). In order to achieve the intensification in already built up areas, municipalities may permit developers to exceed building height and density requirements as outlined in the zoning requirements in lieu of cash through Section 37 of the Planning Act. This density bonusing results in unpredictable building heights and affects modeling potential to gauge shadowing of the surrounding environment.

\subsection{Conflicting Policies}

\subsubsection{Conflicts within Policies}

As outlined above, the Provincial Policy Statement and the Growth Plan for the Greater Golden Horseshoe both prioritize renewable energy production and other identified conflicting priorities such as heritage, green infrastructure and intensification. In the absence of a clear plan to address these conflicting priorities, planners may prioritize one over the other rather than address them synergistically. 
In a city like Toronto, which frequently justifies density and height bonusing due to intensification pressures, absence of solar considerations results in unpredictable irradiation levels both spatially (e.g. inconsistent built form in a neighbourhood) and temporally (e.g. unpredictable whether buildings in the future will affect irradiation onto surrounding built form). Height and density bonusing is a significant source of revenue for Toronto. From 2007 to 2011, Toronto garnered $\$ 136$ million in cash or in-kind benefits (Moore, 2013). This unpredictability is especially salient for property owners considering locking into microFIT and FIT contracts for 20 years as they cannot predict the quantity of revenue generation for that time span.

\subsubsection{Conflicts between Policies}

Renewable energy endeavors evidently conflict with urban canopy cover targets and heritage designations. This means that trees could hinder a building's ability to capture solar energy. Likewise, strict heritage guidelines may prevent solar power technology integration.

In municipalities that do not have a tree by-law, planners may consider addressing solar energy and urban canopy considerations simultaneously in a plan. As outlined previously, before creating the plan, collaboration with the community is crucial, especially in the visioning exercise. The American Planning Association recommends that planners using data-sharing 
software such as mapping tools to identify underutilized sites with high irradiation (e.g. parking lots, brownfields, landfills, big box stores, etc.) and locations of mature trees as well as robust data-tracking for tree removal (APA, 2013).

A similar exercise for developing guidelines on how to integrate various sustainable features including solar energy on heritage buildings can help addresses these conflicting priorities (APA, 2014).

\subsection{Analysis of International Best Practices}

Although not exhaustive, this next section highlights some key international best

practices that could serve as transferable lessons to Ontario. The matrix in Appendix B displays all the grouped case studies by common land use, project type and similar theme that can inform recommendations for the Ontario context. Each cluster highlights main opportunities and barriers that can serve as transferable lessons for Ontario by using the five strategic interventions as a framework. Throughout all five clusters, all five strategic interventions play a role in the success of these projects. For example, vision and goal setting are crucial to ensure public support and ownership of these projects that then translates into plans that encompass these goals. Regulations and incentives ensure the viability of these projects. Financial backing 
either by the private sector or the public sector is key for the success of these projects.

Recommendations are provided based on feasibility in Ontario's planning legislation. The following sections elaborate on the five general themes identified from the matrix.

\subsubsection{Intensification Pressures: Transportation Infrastructure as Sites for Solar Energy}

\section{Production}

Five cases were selected to represent opportunities for using transportation

infrastructure for solar energy generation. These projects outlined in Table 1 range in size from micro scale Barcelona's Solar Bus Stop (New York City Global Partners [NYC GP], 2009) to meso scale such as London's Solar Electric Train, Krommenie's solar bike path, Ouderkerk aan de Amstel's solar noise barrier and the using solar PV as canopy infrastructure over parking lots in Maryland. All of these best practices focus on using marginal land on transportation infrastructure to generate solar energy. This versatility of use exemplifies how solar energy can be integrated at various scales and used for different purposes. For example, in Barcelona individual solar PV panels can provide sufficient energy to operate the bus schedule panels and provide illumination at night (NYC GP, 2009). Scaling up, the Krommenie example is a playful take on energy generation and illumination by incorporating solar energy into bike infrastructure (SolaRoad, n.d.). The roof of the train tunnel connection over the Thames River in London, 
United Kingdom, between the First Capital Connect and London Underground presents a creative example of solar panel incorporation into otherwise unusable space. The electricity generated from these panels is enough to supply $50 \%$ of Blackfriars station (NetworkRail, 2014). The Ouderkerk aan de Amstel example shows how photovoltaic panels can act as noise barriers as well as provide electricity to the neighbouring village (PVResources, n.d.). The Maryland example demonstrates how photovoltaic panels can provide shading and supply power for electric vehicles. The State of Maryland is promoting photovoltaic integration into parking lot infrastructure in order to meet two state goals: renewable energy production and support for electric vehicle infrastructure (Maryland Energy Administration, n.d.).

This versatility of solar integration on marginal lands associated with transportation infrastructure fits for the Greater Golden Horseshoe intensification pressures. The municipalities of Ontario should consider exploring how solar energy might be integrated into transportation infrastructure to generate energy at different scales. In terms of the five strategic interventions, these case studies exemplify the need for plan making, regulations and incentives, development work and public investment. In the short term, municipalities can identify suitable transportation infrastructure for solar energy integration. Medium term goals involve developing master plans for transportation infrastructure which include solar energy integration as potential energy 
generation source that could double as noise barriers, shading infrastructure, illumination or electric fueling areas for electric vehicles. This may involve entering into public private partnerships with the respective property owners of this infrastructure (e.g. Metrolinx, Toronto Transit Corporation or private parking lot owners) or spearheading these projects on their own lands. Medium term changes will also require developing programs to incentivize these initiatives and ensure safety and liability. Municipalities may also want to explore the viability of leasing air rights above these transportation corridors. 
Table 1 Lessons from utilizing transportation infrastructure for solar energy production

\begin{tabular}{|c|c|c|c|c|c|}
\hline & $\begin{array}{l}\text { London, } \\
\text { United } \\
\text { Kingdom }\end{array}$ & $\begin{array}{l}\text { Barcelona, } \\
\text { Spain }\end{array}$ & $\begin{array}{l}\text { Krommenie, } \\
\text { Netherlands }\end{array}$ & $\begin{array}{l}\text { Ouderkerk } \\
\text { aan de } \\
\text { Amstel, } \\
\text { Netherlands }\end{array}$ & $\begin{array}{l}\text { Maryland, } \\
\text { United States }\end{array}$ \\
\hline $\begin{array}{l}\text { Lessons } \\
\text { Learned }\end{array}$ & \multicolumn{5}{|c|}{ Using transportation infrastructure to address intensification pressures. } \\
\hline Project & $\begin{array}{l}\text { Solar Energy } \\
\text { on Train } \\
\text { Tunnel }\end{array}$ & $\begin{array}{l}\text { Solar bus } \\
\text { stop } \\
\text { schedules }\end{array}$ & $\begin{array}{l}\text { Solar bike } \\
\text { path }\end{array}$ & $\begin{array}{l}\text { Solar panels } \\
\text { as highway } \\
\text { noise barrier }\end{array}$ & $\begin{array}{l}\text { Parking lot } \\
\text { solar PV } \\
\text { canopy }\end{array}$ \\
\hline Outcome & $\begin{array}{l}\text { Generates } \\
50 \% \text { of } \\
\text { stations } \\
\text { energy }\end{array}$ & $\begin{array}{l}\text { Powers } \\
\text { electronic bus } \\
\text { schedules } \\
\text { and provides } \\
\text { illumination }\end{array}$ & $\begin{array}{l}\text { Provides } \\
\text { illumination } \\
\text { and } \\
\text { generates } \\
\text { electricity }\end{array}$ & $\begin{array}{l}\text { Provides solar } \\
\text { energy to grid } \\
\text { on marginal } \\
\text { land }\end{array}$ & $\begin{array}{l}\text { Meets } \\
\text { Maryland } \\
\text { State goals for } \\
\text { solar energy } \\
\text { production and } \\
\text { building } \\
\text { electric vehicle } \\
\text { infrastructure }\end{array}$ \\
\hline
\end{tabular}

\subsubsection{Intensification Pressures: Brownfields as Sites for Solar Energy Production}

Former industrial sites that are used to generate solar energy have gained the title of

"brightfields" by the Department of Energy (APA, 2013). The two brightfield best practices

featured in Table 2 are among many American examples that are developing solar energy 
infrastructure on former brownfields. This is commonly occurring in economically depressed municipalities that are looking to provide energy locally, to identify alternative revenue generation sources and to capitalize on large swaths of "blighted" space (APA, 2014). The Brockton case provides an example of a municipality attempting to identify alternative revenue generation uses to industrial in an economically depressed area (De Sousa \& Spiess, n.d.). The Chicago example demonstrates how these vacant lands can provide significant space for large scale energy generation. At the time of construction, the Exelon City Solar project was the largest solar energy-producing source in an urban area generating 14,000 MWH of electricity annually (Exelon Generation, n.d.). This feat was undertaken by the private sector.

In both cases, transferable lessons regarding the adaptive reuse of brownfields may be a viable interim or even a permanent option for former industrial sites in the province. The Ministry of Energy in collaboration with the Ministry of Municipal Affairs and Housing should encourage property owners of underused or closed industrial sites, to remediate their land in order to generate revenue from solar energy production by entering into FIT contracts. This could act as a stepping-stone for complete remediation while generating significant revenue sources. In fact, municipalities should explore how these large swaths of land could be used to 
meet their Community Energy Plan targets by contributing significant energy generation sources.

Short-term considerations for Ontarian municipalities may be to prompt brownfield property owners to generate local energy or lease the private land for energy generation. Municipalities should consider integrating solar energy generation as an interim use on brownfield redevelopment through Community Improvement Plans in order to incentivize this endeavor. Given the lack of precedents, Ontario will have to determine guidelines for proper solar energy integration on brownfields taking into consideration liability, remediation and decommissioning (APA, 2014).

Table 2 Lessons from utilizing brownfields for solar energy production

\begin{tabular}{|l|l|l|}
\hline \multicolumn{4}{|c|}{$\begin{array}{c}\text { Brockton, United States } \\
\text { of America (USA) }\end{array}$} \\
\hline $\begin{array}{l}\text { Lessons } \\
\text { Learned }\end{array}$ & \multicolumn{2}{|c|}{$\begin{array}{c}\text { Chicago, USA } \\
\text { Adaptive reuse of brownfields into 'brightfields' }\end{array}$} \\
\hline Project & $\begin{array}{l}\text { 3.7 acre/ 27 acre used for solar energy } \\
\text { production (De Sousa \& Spiess, n.d.) }\end{array}$ & $\begin{array}{l}\text { 41 acres, produces 14,000 } \\
\text { megawatt-hours of electricity per } \\
\text { year (Exelon Generation, n.d.) }\end{array}$ \\
\hline Outcome & $\begin{array}{l}\text { Using industrial contaminated site; job } \\
\text { creation(De Sousa \& Spiess, n.d.) }\end{array}$ & $\begin{array}{l}\text { Former brownfield property; vacant } \\
\text { for 30 years } \\
\text { (Exelon Generation, n.d.). }\end{array}$ \\
\hline
\end{tabular}




\subsubsection{Establishing an International Reputation as a Solar City}

Gore \& Robinson (2009) discuss how one of the motivators for municipalities to implement sustainability initiatives is their concern for their international reputation. Several cities are taking this opportunity stand out in the international community by branding themselves as sustainable cities. A key to their success is using solar energy. The best practices presented in Table 3 are Malmo, Sweden; Freiburg, Germany; and Seoul, South Korea. They have all distinguished themselves internationally as some derivative of a 'sustainable community.' In all these cases, solar energy is a significant supply of onsite energy generation. Germany's Freiburg has a reputation in sustainable development that dates back to the 1970s after the Chernobyl nuclear accident (Oliveira, Bragança, 2012). Since this time, the municipality has actively sought reducing its fossil fuel dependency by promoting locally produced energy from renewable sources such as solar. Seoul, South Korea committed to putting solar photovoltaic cells on 10,000 roofs in order to generate $290 \mathrm{MW}$ of energy within the city (ICLEI, 2013). The municipality of Malmo aspires to run on 100\% renewable energy such as solar energy, biogas and wind by 2030 (Malmö stad, 2011). As a result, these municipalities have gained international recognition and awards for their efforts. 
There are not many case precedents of municipalities in Canada intentionally integrating solar energy into neighbourhood scale plans. The existing Drake's Landing (Okotoks, Alberta) is among the few developments that have integrated solar energy on a district scale. The interesting parts of the international case studies are that solar energy is one feature among several contributing factors to a holistic design. These districts serve as exemplary cases for Ontario as they can show that mixed-use communities can incorporate solar energy technologies at various scales. The closest example to this in the Ontario context is the not-yet developed "Village at River Bend" community in London Ontario. This community has been intentionally designed to maximize on solar energy through the built form as well as produce local food, provide electric vehicle charging stations and include low-impact water infrastructure (Parnis et al., 2014).

Ontario can build on its London example and the voluntary initiatives developed by municipalities like Toronto Green Standards to further encourage developers to integrate solar energy in their development plans. As a whole, the Province should be pushing municipalities to develop sustainable neighbourhoods that include onsite energy generation through the use of solar energy. A critical role that the Ministry of Municipal Affairs and Housing can play in promoting sustainable communities development is by creating guidelines and standards for 
solar energy integration into the built form as well as providing funding to support the

undertaking of these projects. The Province can also partner with other organizations, such as

academics or the Canadian Planning Institute, to promote solar energy in urban planning to

professionals and the general public through public outreach and information dissemination.

Table 3 Lessons from internationally recognized sustainable cities using solar energy

\begin{tabular}{|c|c|c|c|}
\hline & Malmo, Sweden & Freiburg, Germany & Seoul, South Korea \\
\hline $\begin{array}{l}\text { Lessons } \\
\text { learned }\end{array}$ & $\begin{array}{l}\text { "Sweden's most climate } \\
\text { friendly city" (Malmö } \\
\text { stad, 2011) }\end{array}$ & $\begin{array}{l}\text { "Ecological Capital of } \\
\text { Germany" (PVupscale, } \\
\text { 2007) }\end{array}$ & $\begin{array}{l}\text { "City of Sunlight" } \\
\text { (ICLEI, 2013) }\end{array}$ \\
\hline Project & $\begin{array}{l}\text { Solar energy, wind } \\
\text { energy and biogas will } \\
\text { fuel the city }\end{array}$ & $\begin{array}{l}\text { Integrated solar energy } \\
\text { into new construction } \\
\text { projects }\end{array}$ & $\begin{array}{l}\text { Photovoltaic panels will } \\
\text { be installed on 10,000 } \\
\text { rooftops (ICLEI, 2013) }\end{array}$ \\
\hline Outcome & $\begin{array}{l}\text { The Campaign for } \\
\text { Take-off Award, } 2000 \\
\text { (Svekom, 2003) }\end{array}$ & $\begin{array}{l}\text { Germany's Federal } \\
\text { Capital for Climate } \\
\text { Protection in } 2010 \\
\text { (Energy Cities, 2010) }\end{array}$ & $\begin{array}{l}\text { WWF, National Earth } \\
\text { Hour Award } 2014 \\
\text { (WWF, 2014); City } \\
\text { Climate Leadership } \\
\text { Award } 2014 \text { (WWF, } \\
\text { 2014) }\end{array}$ \\
\hline
\end{tabular}

\subsubsection{Solar Energy Mapping in Resiliency Plans}

Ontario is currently renewing its strategy on climate change adaptation. An interesting

approach would be to look at how the American Solar Cities have incorporated solar energy into 
their resiliency plans. For the sake of brevity, the cities of New York and Boston were researched and are outlined in Table 4. Interestingly, both municipalities where driven to incorporate solar energy into their Emergency Preparedness plans in the wake of Hurricane Sandy (Local Governments for Sustainability [ICLEI], 2014). The City of Boston is exploring options for running the intersection lights on solar energy to facilitate evacuation (Belden, n.d.) whereas New York is incorporating solar energy into the water and sewage wastewater infrastructure to allow it to function even during a disaster period (ICLEI, 2014).

Given Ontario's aging infrastructure, coupled with the changing climate and unpredictable disasters, municipalities should explore the role of solar energy as a resiliency tool. In the short term, Ontario municipalities can seek to incorporate solar energy as in their integrated community sustainability and resiliency plans by highlighting the benefits of solar power during disaster periods. The Province can provide direction to the municipalities by incorporating solar energy in the provincial climate change adaptation plan. Through education outlets, the Province can provide educational resources to the public to describe the various ways solar energy help during times of disasters. 
Table 4 Lessons from resiliency plans using solar energy

\begin{tabular}{|l|l|l|}
\hline \multicolumn{2}{|l|}{ Boston, USA } \\
\hline Lessons Learned & \multicolumn{2}{l|}{ Solar energy for climate change adaptation and disaster mitigation } \\
\hline Project & Boston Solar Evacuation Pilot Project & $\begin{array}{l}\text { New York City's Plan NYC A } \\
\text { Stronger More Resilient }\end{array}$ \\
\hline Outcome & $\begin{array}{l}\text { Utilize solar energy to enable } \\
\text { evacuation in the chance of a disaster } \\
\text { (Belden, n.d.) }\end{array}$ & $\begin{array}{l}\text { Incorporate solar energy for } \\
\text { water and wastewater } \\
\text { infrastructure (ICLEI, 2014) }\end{array}$ \\
\hline
\end{tabular}

\subsubsection{Solar Energy for Climate Change Mitigation}

Ontario municipalities share the provincial goal to reduce greenhouse gases by $15 \%$

below 1990s levels by 2020 (OMOE, 2007). New York City and Halifax Regional Municipality are two examples of municipalities that have integrated solar energy into their strategies for reaching their GHG reduction target (United States Department of Energy [DOE], 2011; FCM, 2015) as shown in Table 5. More specifically, through collaborative and innovative projects involving various private and public stakeholders, these municipalities garnered significant financing for solar energy projects. The success solar energy uptake has gained them the titles of "Solar City" in their respective countries (FCM 2015; DOES, 2010). New York City is among 
25 cities to participate in the federal American government "Solar America Cities" program funded by the DOE (DOE, 2010).

The key to successful solar energy implementation in both Halifax Regional Municipality and New York City was the solar energy-mapping tool. Halifax Regional Municipality (HRM) was the first municipality in Canada to use solar energy mapping to identify areas of high insolation (FCM, 2015). This mapping tool was used to support and promote solar energy technologies in areas of high solar power potential. The project was spearheaded by the municipality and supported by the FCM Energy Fund, and the HRM was able to loan property owner's money to install solar water heaters through the Local Improvement Charges (FCM, 2015). The map is a basic user-friendly tool that allows property owners to determine the average annual amount of solar radiation on their buildings, based on factors such as shading and roof elevation (Ewarts, Jahncke \& Fraser, 2009).

The New York City solar map is a more elaborate interactive tool that, in addition to providing the solar potential for a building, provides existing solar installations, real-time solar energy production of the city and available incentives. It even allows the user to draw a hypothetical solar energy system on the buildings and run financial feasibility analyses to determine how much power these systems could generate. It also tracks existing buildings with 
solar installations so that the general public can stay informed on what kind of systems are presently available in the city (The City University of New York [CUNY], n.d.). Significant funding to develop these maps was provided by the federal programs supporting renewable energy (DOE, 2012).

New York City has also launched a project called the "Solar Empowerment Zones" (DOE, 2011) whereby three zones with high solar energy potential have been identified as key locations for piloting policies and incentives (DOE, 2011). These areas were also selected as pilot zones as they need network infrastructure upgrades and have a significant amount of rooftop space for solar PV installations (DOE, 2011).

In both cases, these maps serve the municipality as powerful educational tools to demonstrate the viability of solar energy across the macro scale. As part of innovative and demonstrative projects, both municipalities are tracking solar energy uptake to determine performance (DOE, 2011; FCM, 2015).

Ontario can consider short, medium and long-term actions to proactively identify and take advantage of high insolation on the existing building stock. Solar energy maps are a powerful tool to engage the public as well as to inform the municipal staff on identifying parts of the city that are ideally suited for the implementation of solar energy projects. In the short term, 
the Ministry of Municipal Affairs and Housing can encourage municipalities to incorporate solar energy mapping to the existing available energy-mapping tool to inform their land use decisionmaking process. Taking it a step further, on a site-by-site basis, Ontario municipalities may seek to reassess their sun/shadow study in light of solar energy mapping to determine the effect of the projected future development on the surrounding built form. In order to guarantee solar energy potential over a longer duration, municipalities may consider using solar energy mapping and performance tracking to protect areas of prime solar radiation.

In the medium term, the solar energy-mapping tool could be used to update the zoning by-law or even create a 'solar friendly' development permit system to address solar energy potential on a neighbourhood scale. Planners could identify the zones in the municipality with high insolation in order to reassess these areas' height and density targets. Zoning in these areas could be reassessed to maximize on high solar potential for both active and passive solar energy gains. These areas of high solar potential could also act as pilot areas, similar to New York City to test out different policies and incentives for solar energy promotion and track performance. In the long-term, laws protecting solar access such as a 'right to light,' could be considered to ensure that future development does not obstruct solar energy systems. 
Table 5 Lessons from municipalities reducing greenhouse gas emissions through solar energy programs

\begin{tabular}{|l|l|l|}
\hline \multicolumn{3}{|c|}{ Halifax Regional Municipality, } \\
\multicolumn{2}{|c|}{ Canada } \\
\hline $\begin{array}{l}\text { Lesson } \\
\text { Learned }\end{array}$ & Solar energy programs to reduce greenhouse gas emissions \\
\hline Project & $\begin{array}{l}\text { Solar mapping; education; tracking } \\
\text { performance }\end{array}$ & $\begin{array}{l}\text { Solar mapping; education; data } \\
\text { tracking }\end{array}$ \\
\hline Outcome & "Solar City" (FCM, 2015) & $\begin{array}{l}\text { Solar America Cities "Solar City" } \\
\text { (DOE, 2011) }\end{array}$ \\
\hline
\end{tabular}

\subsection{Commonalities amongst Best Practices}

Ontario should explore the merits of the 'right to light' legislation to ensure solar energy

systems are not hindered by future development or other provincial priorities. Nevertheless,

there are several steps the Ministry of Municipal Affairs and Housing and the Ministry of Energy

could take to promote and support solar energy projects in the short and medium term through

improved land use planning. Ultimately, before any new regulation or solar-friendly plan is

developed, there is a need for education on solar energy. The Province, in collaboration with

other partners, be it academics, the energy sector, the private sector or the Ontario Professional 
Planning Institute could collaborate on developing curriculums to inform municipalities and planners on the considerations of solar energy in land use planning. This 'solar energy in urban planning' curriculum could be disseminated via continuing professional development programs. Embedded in the planning curriculum, programs offering planning courses could emphasize the necessity of ICLES in order to make better informed planning decisions with regards to solar energy. With improved education through the curriculum, pilot projects and energy mapping tools, community members and practitioners can gain a better understanding of the potential for solar energy in the urban landscape.

The Federal government through its existing sustainability financing programs (i.e. FCM Energy Fund and the Gas Tax Fund) and through the Federal Sustainable Development Strategy could also incentivize and promote solar initiatives. In order for solar energy to be viable, planners should consider the solar energy potential at a jurisdictional scale. This means determining how solar energy can be further supported by the existing suite of regulatory tools such as the development permit system, zoning by-law, air rights, community improvement plans and density and height bonusing. Incentive programs could be developed to further promote solar energy integration, both for the private sector and public sector. 


\section{Recommendations}

The following recommendations discuss possible avenues for enabling solar energy in urban planning in Ontario:

\subsection{Short Term}

1. The Ministry of Municipal Affairs and Housing could explore partnering with the Ontario Professional Planning Institute and Canadian Institute of Planners to develop solar energy education material for planners.

2. Organizations such as the Canadian Urban Institute, Quality Urban Energy Systems of Tomorrow, the Ontario Professional Planning Institute and the Federation for Canadian Municipalities should consider developing a 'solar energy in urban planning' toolkit for municipalities to address conflicting provincial policies such as urban canopy, heritage and intensification.

3. Partners such as the Canadian Urban Institute, Quality Urban Energy Systems of Tomorrow, the Ontario Professional Planning Institute and the Federation for Canadian Municipalities should consider promoting the development of solar energy mapping to municipalities to identify sites of high insolation as best practices.

4. The Ministry of Municipal Affairs and Housing can encourage municipalities to incorporate solar energy mapping to the existing available energy-mapping tool to inform 
their land use decision-making process and encourage solar energy production in suitable parts of their jurisdiction.

\subsection{Medium Term}

1. Through the Ministry of Municipal Affairs and Housing, explore integrating solar energy considerations via the development permit system or zoning by-law in areas identified with high solar power potential.

2. The Ministry of Municipal Affairs and Housing should explore developing guidelines on integrating solar energy into official plans and other municipal plans such as transportation plans to foster 'solar ready' municipalities.

\subsection{Long Term}

1. The Ministry of Environment and the Ministry of Energy should consider requesting a study on the 'right to light' legislation that balances and makes concessions for the conflicting priorities by the Law Commission of Ontario.

2. Municipalities and the Province should request greater federal support to promote solar energy initiatives. 


\section{Conclusion}

Municipalities across the world are paving the way for solar integration through

innovative projects and plans. Ontario has a unique window of opportunity to think about solar

energy in urban planning, in light of provincial plan updates, and help its municipalities be on par

with these other cities around the world. Ontario can capitalize on the successful microFIT and

FIT program and think about solar energy strategically as a resource worth planning for. As this

paper highlights, there are definite benefits to planning for solar energy, in terms of the

environment, economy and versatility in integration. In the same way as designers are

developing 'solar ready' homes, planners have to take into consideration all provincial priorities

and devise official plans at the municipal level that are 'solar ready' as well. Solar energy can

also be better integrated through various other municipal initiatives such as the integrated

community sustainability plans, transportation plans and resiliency plans. Planners hold a key

role in the successful deployment of solar energy: may it be a step among many to come in working with the energy sector to create sustainable communities. 


\section{Appendix A}

\section{Examples of Solar Energy Considerations in the London Official Plan Draft}

"Streets \& Streetscapes:

"5. Street layouts, lot sizes, layout, and building orientation will be designed to take advantage of passive solar energy."

Site Layout

8. Buildings will be sited and oriented to take advantage of passive solar energy.

Green Development

802. Wherever possible, new developments will be planned to be "future ready" to accommodate the future use of solar energy, electric vehicles, and (where applicable) district energy systems. Standards may be developed to require that neighbourhoods or individual buildings are developed to a meet specific sustainability measures or standards." 


\section{Appendix B}

Summary matrix of case studies reviewed grouped by cluster theme, lesson for Ontario, potential drivers and barriers in the Ontario context and the recommendations

\begin{tabular}{|c|c|c|c|c|c|c|c|}
\hline Type & Location \& Project & Cluster Theme & $\begin{array}{l}\text { Transferable Lesson for } \\
\text { Ontario }\end{array}$ & Drivers in Ontario Context & $\begin{array}{l}\text { Barriers in the Ontario } \\
\text { Context }\end{array}$ & $\begin{array}{l}\text { Recommendation } \\
\text { Considerations (Short } \\
\text { Term) }\end{array}$ & $\begin{array}{l}\text { Recommendation } \\
\text { Considerations (Medium to } \\
\text { Long Term) }\end{array}$ \\
\hline $\begin{array}{l}\text { Transportation } \\
\text { Infrastructure }\end{array}$ & $\begin{array}{l}\text { London, United } \\
\text { Kingdom; Barcelona, } \\
\text { Spain; Krommenie, } \\
\text { Netherlands; } \\
\text { Ouderkerk aan de } \\
\text { Amstel, Netherlands; } \\
\text { Maryland, United } \\
\text { States of America } \\
\text { (USA) }\end{array}$ & $\begin{array}{l}\text { Solar energy integrated } \\
\text { into transportation } \\
\text { infrastructure for } \\
\text { electricity generation }\end{array}$ & $\begin{array}{l}\text { Using marginal lands due to } \\
\text { intensification pressures for } \\
\text { solar energy generation }\end{array}$ & $\begin{array}{l}\text { Local energy autonomy, } \\
\text { intensification pressures, } \\
\text { innovation }\end{array}$ & $\begin{array}{l}\text { No precedence of leasing air } \\
\text { rights on transportation } \\
\text { infrastructure for renewable } \\
\text { energy generation in Ontario }\end{array}$ & $\begin{array}{l}\text { Pilot solar integration on } \\
\text { transportation corridors }\end{array}$ & $\begin{array}{l}\text { Medium - Develop } \\
\text { Transportation Plans that } \\
\text { include solar energy } \\
\text { considerations; Develop } \\
\text { regulations and incentive } \\
\text { programs for solar } \\
\text { integration; Consider entering } \\
\text { into public private } \\
\text { partnerships to promote solar } \\
\text { energy integration; Explore } \\
\text { leasing air rights for solar } \\
\text { energy integration. }\end{array}$ \\
\hline Brownfields & $\begin{array}{l}\text { Chicago, USA; } \\
\text { Brockton, USA }\end{array}$ & $\begin{array}{l}\text { Brownfield be used as } \\
\text { sites for solar energy } \\
\text { generation }\end{array}$ & $\begin{array}{l}\text { Exploring how local energy } \\
\text { generation targets in } \\
\text { Community Energy Plans can } \\
\text { be met from brownfield } \\
\text { redevelopment. }\end{array}$ & $\begin{array}{l}20 \text { year FIT contracts aligned } \\
\text { with interim use of space; } \\
\text { local energy autonomy }\end{array}$ & $\begin{array}{l}\text { Intensification pressures; } \\
\text { unprecedented in Ontario }\end{array}$ & $\begin{array}{l}\text { Pilot solar energy projects on } \\
\text { brownfield sites in areas with } \\
\text { reduced }\end{array}$ & $\begin{array}{l}\text { Medium - Develop standards } \\
\text { and guidelines for solar } \\
\text { energy integration on } \\
\text { brownfields; Consider } \\
\text { entering into public private } \\
\text { partnerships to promote solar } \\
\text { energy integration. }\end{array}$ \\
\hline $\begin{array}{l}\text { Neighbourhood/ } \\
\text { Precinct }\end{array}$ & $\begin{array}{l}\text { Freiburg, Germany; } \\
\text { Malmo, Sweden; } \\
\text { Seoul, South Korea }\end{array}$ & \begin{tabular}{|l} 
Solar energy \\
contributing to local \\
energy supply for \\
mixed-use \\
development
\end{tabular} & $\begin{array}{l}\text { Master plans provides clear } \\
\text { targets on onsite renewable } \\
\text { energy production; details } \\
\text { solar energy contribution }\end{array}$ & $\begin{array}{l}\text { local energy autonomy; } \\
\text { reputation }\end{array}$ & Unprecedented & $\begin{array}{l}\text { Encourage municipalities to } \\
\text { include solar energy in } \\
\text { community improvement } \\
\text { plans; Develop clear } \\
\text { guidelines for solar energy } \\
\text { integration in development } \\
\text { plans; Create education } \\
\text { programs on solar energy in } \\
\text { urban planning }\end{array}$ & $n / a$ \\
\hline City Scale & \begin{tabular}{|l|} 
Boston, USA; \\
New York City, USA
\end{tabular} & $\begin{array}{l}\text { Incorporated solar } \\
\text { energy into emergency } \\
\text { preparedness for the } \\
\text { city to maintain power } \\
\text { supply in the event of a } \\
\text { crisis } \\
\end{array}$ & $\begin{array}{l}\text { Climate change adaptation } \\
\text { plans and emergency } \\
\text { preparedness plans can } \\
\text { incorporate solar energy }\end{array}$ & $\begin{array}{l}\text { Climate change adaptation } \\
\text { initiatives }\end{array}$ & Financing; unprecedented & $\begin{array}{l}\text { Encourage municipal ICSP } \\
\text { and resiliency plans to } \\
\text { include solar energy; } \\
\text { Incorporate solar energy in } \\
\text { climate change adaptation } \\
\text { plan }\end{array}$ & $n / a$ \\
\hline City Scale & $\begin{array}{l}\text { New York City, USA; } \\
\text { Halifax Regional } \\
\text { Municipality, Canada }\end{array}$ & \begin{tabular}{|l} 
City scale solar \\
developments by \\
setting clear solar \\
targets and identifying \\
strategic solar zones \\
using solar energy \\
mapping
\end{tabular} & $\begin{array}{l}\text { Cross-disciplinary approach } \\
\text { using mapping tools, zoning, } \\
\text { and educational resources. } \\
\text { Upper governmental support } \\
\text { directed at solar integration. }\end{array}$ & $\begin{array}{l}\text { Reduce GHG emissions; } \\
\text { reputation }\end{array}$ & $\begin{array}{l}\text { Unprecedented 'solar city' } \\
\text { approach in Ontario. Current } \\
\text { regulations do not factor in } \\
\text { solar considerations; no solar } \\
\text { access protection }\end{array}$ & $\begin{array}{l}\text { Promote energy mapping to } \\
\text { determine areas of high } \\
\text { irradiation; Expand on } \\
\text { sun/shadow study to include } \\
\text { cast shadow on surrounding } \\
\text { buildings; Track solar energy } \\
\text { uptake. }\end{array}$ & $\begin{array}{l}\text { Medium - Encourage } \\
\text { municipalities updating zoning } \\
\text { by law or DPS can engage } \\
\text { community to include solar } \\
\text { considerations } \\
\text { Long - establish solar access } \\
\text { laws; Bolster federal support } \\
\text { of solar initiatives. }\end{array}$ \\
\hline
\end{tabular}




\section{Reference List}

American Planning Association. (2013). Planning for solar energy briefing papers. Retrieved from https://www.planning.org/research/solar/briefingpapers/pdf/solarpaperscompendium.pdf

American Planning Association. (2014). Planning for solar energy. D. Morley.(Ed.). Chicago, IL: Morley.

American Planning Association. (2015). Using solar energy to enhance community resilience [PowerPoint slides]. Retrieved from https://www.planning.org/research/solar/resiliencewebinar.htm

Belden, A. (n.d.). The Boston solar evacuation route pilot: building emergency and transportation systems resiliency. [report] Meister Consultant Group

Burch, S. (2010). Transforming barriers into enablers of action on climate change: insights from three municipal case studies in British Columbia, Canada. Global Environmental Change, 20(2), 287-297.

Canadian Institute of Planners. (2004). CIP Statement of Values and Code of Professional Practice. Ottawa

Canadian Solar Industries Association. (2014). Roadmap 2020: Powering Canada's future with solar electricity. Retrieved from http://cansia.ca/sites/default/files/cansia_roadmap_2020_final.pdf

Canadian Urban Institute. (2011). Integrated community mapping for Ontario communities: Lessons learned report. Retrieved from http://static1.squarespace.com/static/546bbd2ae4b077803c592197/t/54b807a6e4b060f2e97 45d1e/1421346726645/CUIPublication. IntegratedEnergyMappingOntario.pdf

Catita, C., Redweik, P., Pereira, J., \& Brito, M. C. (2014). Extending solar potential analysis in buildings to vertical facades. Computers \& Geosciences, 66, 1-12.

City of London Corporation. (2014a). City of London: Community energy action plan (20142018): Part of London's Community Energy Action Program. Retrieved from 
http://www.london.ca/residents/Environment/Energy/Documents/Community\%20Energy\%20 Plan.pdf

City of London Corporation. (2014b). The London Plan draft. Retrieved from http://thelondonplan.ca/full.php

City of Toronto. (2010). Toronto Green Standards: Making a sustainable city happen. Retrieved from

http://www1.toronto.ca/city_of_toronto/city_planning/developing_toronto/files/pdf/lr_res_tech. pdf

City of Toronto. (2015). Reset TO. Retrieved from http://www1.toronto.ca/wps/portal/contentonly?vgnextoid=3b2cd9e27ac93410VgnVCM10000 071d60f89RCRD

City University of New York. (n.d.). NYC solar map. Retrieved from http://www.cuny.edu/about/resources/sustainability/solar-america/map.html

DeKay, R. M. (2012). Climatic urban design: configuring the urban fabric to support daylighting, passive cooling, and solar heating. In the Sustainable City VII, Vol 2. Pg 619.

Deshmukh, R., Bharvirkar, R., Gambhir, A., \& Phadke, A. (2011). Analysis of international policies in the solar electricity sector. Prayas and Lawrence Berkeley National Laboratory.

De Sousa, C., \& Spiess, T. B. (n.d.). Brockton Brightfield, Brockton, Massachusetts: A sustainable brownfield revitalization best practice. Retrieved from https://www.uic.edu/orgs/brownfields/research-results/documents/BrocktonBrightfieldfinalforposting-May102013.pdf

Droege, P. (2006). The renewable city: a comprehensive guide to an urban revolution. Chichester, UK: Wiley-Academy.

Energy Cities. (2010, November 2). Freiburg- German capital of climate protection. Retrieved from http://www.energy-cities.eu/Freiburg-German-Capital-of-climate

Environment Canada. (2012). Assessment of the environmental performance of solar 
photovoltaic technologies. Retrieved from http://www.ec.gc.ca/scitech/B53B14DE-034C457B-8B2B-

39AFCFED04E6/ForContractor_721_Solar_Photovoltaic_Technology_e_09\%20FINALupdate\%202-s.pdf

Environment Canada. (2013). Planning for a Sustainable Future: A Federal Sustainable Development Strategy for Canada 2013-2016. Retrieved from https://www.ec.gc.ca/ddsd/default.asp?lang=En\&n=A22718BA-1

Environmental Commissioner of Ontario. (2013). Review of the Ontario government's climate change action plan results: Annual greenhouse gas progress report 2013. Toronto, ON: Queen's Press

Environmental Protection Act. Revised Statute of Ontario. (1990 c. E. 19). Retrieved from Legislative Assembly of the Province of Ontario http://www.elaws.gov.on.ca/html/statutes/english/elaws_statutes_90e19_e.htm

Evarts, J., Jahncke, R., Fraser, C. (2009). Halifax solar map. Retrieved from http://maps.halifax.ca/solarcity/solarmap.html

Evenson, K., Margerm, K., McDonough, A. (2013). Advancing integrated community energy planning in ontario: A primer. Retrieved from http://questcanada.org/sites/default/files/files/The\%20Primer\%20-\%20reduced\%20size.pdf

Exelon Generation. (n.d.) Exelon City Solar. Retrieved from http://www.exeloncorp.com/assets/energy/powerplants/docs/pdf_ExelonCitySolarFact.pdf

Federation of Canadian Municipalities. (n.d.). Green municipal fund. Retrieved from http://www.fcm.ca/home/programs/green-municipal-fund.htm

Federation of Canadian Municipalities. (2014). Examples of municipal sustainable community plans or strategies. Retrieved from http://www.fcm.ca/home/programs/green-municipalfund/examples-of-municipal-sustainable-community-plans-or-strategies.htm 
Federation of Canadian Municipalities. (2015). 2015 Energy program: Halifax Regional Municipality, Nova Scotia. Retrieved from http://www.fcm.ca/home/awards/fcm-sustainablecommunities-awards/2015-winners/2015-energy-program.htm

Gibson, G. (2014). Finding the balance: Solar access in the intensified city. Report prepared for Sector Growth \& Sector Development Office, City of Toronto, Canada.

Good, C. S., Lobaccaro, G., \& Hårklau, S. (2014). Optimization of solar energy potential for buildings in urban areas-A Norwegian case study. Energy Procedia, 58, 166-171.

Gore, C., \& Robinson, P. (2009). Local government response to climate change: Our last, best hope. Changing climates in North American politics: Institutions, policymaking, and multilevel governance, 137-158.

Green Energy Act. Statute of Ontario (2009, c-12, Bill 150). Retrieved from the Legislative Assembly of the Province of Ontario website: http://www.elaws.gov.on.ca/html/source/statutes/english/2009/elaws_src_s09012_e.htm

Hachem, C., Athienitis, A., \& Fazio, P. (2011). Investigation of solar potential of housing units in different neighborhood designs. Energy and Buildings, 43(9), 2262-2273.

Haines, G. (2014). Research in progress for the IEA SHC Task 51 on solar energy opportunities and barriers. (unpublished). Ryerson University, Toronto, Canada.

Hamin, E. M., \& Gurran, N. (2009). Urban form and climate change: Balancing adaptation and mitigation in the US and Australia. Habitat international, 33(3), 238-245.

Identification and mobilization of Solar Potential via Local Strategies. (2012). Identification and mobilization of solar potentials via local strategies: Guidelines based on the experiences of pilot actions, Intelligent Energy Europe.

Independent Electricity System Operator. (2015). Pricing and payment. Retrieved from http://fit.powerauthority.on.ca/program-resources/faqs/pricing-and-payment

Infrastructure Canada. (2014). Green Infrastructure Fund. Retrieved from http://www.infrastructure.gc.ca/prog/gif-fiv-eng.html 
Infrastructure Canada. (2012). Wawa generating its own solar energy thanks to federal Gas Tax Funding. Retrieved from http://www.infrastructure.gc.ca/media/newsnouvelles/2012/20120116wawa-eng.html

Infrastructure Canada (2012). Ramara Township celebrates completion of solar rooftop panels thanks to Federal Gas Tax Funding. Retrieved from http://www.infrastructure.gc.ca/media/news-nouvelles/2012/20120703ramara-eng.html Infrastructure Canada. (2013). City of Brockville adds solar roof to Memorial Centre Arena with Green Municipal Fund and Federal Gas Tax Fund Support. Retrieved from http://www.infrastructure.gc.ca/media/news-nouvelles/2013/20130322brockville-eng.html

Infrastructure Canada. (2014). Building a green community. Retrieved from http://www.infrastructure.gc.ca/regions/on/on-prof-eng.html

International Energy Agency. (2014). Technology roadmap: Solar photovoltaic energy. Retrieved from https://www.iea.org/publications/freepublications/publication/TechnologyRoadmapSolarPhoto voltaicEnergy_2014edition.pdf

Intergovernmental Panel on Climate Change. (2014). Summary for Policymakers. In: Climate Change 2014: Mitigation of Climate Change. Contribution of Working Group III to the Fifth Assessment Report of the Intergovernmental Panel on Climate Change [Edenhofer, O., R. Pichs-Madruga, Y. Sokona, E. Farahani, S. Kadner, K. Seyboth, A. Adler, I. Baum, S. Brunner, P. Eickemeier, B. Kriemann, J. Savolainen, S. Schlömer, C. von Stechow, T. Zwickel and J.C. Minx (eds.)]. Cambridge University Press, Cambridge, United Kingdom and New York, NY, USA.

International Renewable Energy Agency. (2015). Renewable power generation costs in 2014. Retrieved from http://www.irena.org/DocumentDownloads/Publications/IRENA_RE_Power_Costs_2014_rep ort.pdf 
Kanters, J., \& Horvat, M. (2012). Solar energy as a design parameter in urban planning. Energy Procedia, 30, 1143-1152.

Lanz, D. (2014). Green bonds for a Green Economy: considerations for Ontario. Retrieved from Canadian Centre for Policy Alternatives Ontario Office: https://www.policyalternatives.ca/sites/default/files/uploads/publications/Ontario\%20Office/20 14/03/Green\%2520BondsFINAL.pdf

Law Reform Commission of Saskatchewan. (2007) Background paper: Solar access legislation. Report prepared for the Saskatchewan Environment Minister, Regina, Canada.

Ling, C., Hanna, K., \& Dale, A. (2009). A template for integrated community sustainability planning. Environmental Management, 44(2), 228-242.

Lobaccaro, G., \& Frontini, F. (2014). Solar energy in urban environment: how urban densification affects existing buildings. Energy Procedia, 48, 1559-1569.

Local Governments for Sustainability. (2013). Seoul, Republic of Korea: The "one less nuclear power plant initiative." Retrieved from https://seors.unfccc.int/seors/attachments/get_attachment?code=XUNGTLOBW3S2GMHTX 783XFE7E7KJYMCB

Local Governments for Sustainability. (2014). Solar energy \& resilience planning: a practical guide for local governments.ICLEI, USA: Schmidt.

Malmö stad. (2011). Sustainable City Malmö. Retrieved from http://malmo.se/download/18.3744cbfb13a77097d87462f/1383649555324/Hallbar_stad_eng _2011.pdf

Manning, P., Vince, J. (2010, January). Municipalities and the Green Energy Act: Benefits, burdens and the loss of power. Municipal World, p. 5-8.

Maryland Energy Administration. (n.d.). Parking lot solar PV canopy with electric vehicle charger grant program. Retrieved from http://energy.maryland.gov/Commercial/PVEVProgram.htm 
McLaughlin, D. V. P., McDonald, N. C., Nguyen, H. T., \& Pearce, J. M. (2010). Leveraging solar photovoltaic technology for sustainable development in ontario's aboriginal communities. Journal of Sustainable Development, 3(3), 3-13. Retrieved from http://ezproxy.lib.ryerson.ca/login?url=http://search.proquest.com/docview/818856065?accou ntid $=13631$

Miles, M. B., Huberman, A. M., \& Saldaña, J. (2013). Qualitative data analysis: A methods sourcebook. SAGE Publications, Incorporated.

Moore, A. A. (2013). Trading density for benefits: Toronto and Vancouver compared.

Municipal Act. Statute of Ontario. (2001, c. 25). Retrieved from Legislative Assembly of the Province of Ontario http://www.elaws.gov.on.ca/html/statutes/english/elaws_statutes_01m25_e.htm\#BK151

Natural Resources Canada. (2014). Tax savings for industry. Retrieved from http://www.nrcan.gc.ca/energy/efficiency/industry/financial-assistance/5147

Natural Resources Canada. (2014). Energy innovation roundtables report. Retrieved from http://www.nrcan.gc.ca/sites/www.nrcan.gc.ca/files/energy/files/pdf/140309\%20Energy\%20Innovation\%20Roundtable_e.pdf

Network Rail. (2014, January 22). World's largest solar powered bridge makes Britains biggest brew. Retrieved from http://www.networkrail.co.uk/news/2014/jan/Worlds-largest-solarpowered-bridge-makes-Britains-biggest-brew/

Neuman, W. L. (2011). Social research methods: qualitative and quantitative approaches. 6th ed. Pearson.

New York City Global Partners. (2011). Best practice: Promoting solar energy. Retrieved from http://www.nyc.gov/html/unccp/gprb/downloads/pdf/Barcelona_SolarEnergy.pdf

Oliveira, P. A. F. J., \& Bragança, L. (2012). Urban rehabilitation towards sustainability. Paper presented at the C-TAC - Comunicações a Conferências Nacionais, Universidade do Minho 
Ontario Energy Board (OEB). (2014). Information for generators. Retrieved from http://www.ontarioenergyboard.ca/oeb/Industry/Rules\%20and\%20Requirements/Information \%20for\%20Generators/What\%20Initiatives\%20are\%20Available

Ontario Financing Authority. (2014). Green bond Q\&A. Retrieved from http://www.ofina.on.ca/pdf/green_bond_faq.pdf

Ontario Heritage Act. Revised Statute of Ontario (2006, c. 0.18). Retrieved from the Legislative Assembly of the Province of Ontario http://www.elaws.gov.on.ca/html/regs/english/elaws_regs_060009_e.htm

Ontario Ministry of Energy (2013). Conservation first: A renewed vision for energy conservation in Ontario. Retrieved from http://www.energy.gov.on.ca/en/conservation-first/

Ontario Ministry of Energy. (2014). Ontario's municipal energy plan program. Retrieved from http://www.energy.gov.on.ca/en/municipal-energy/

Ontario Ministry of Energy. (2015). Conservation for public agencies. Retrieved from http://www.energy.gov.on.ca/en/green-energy-act/conservation-for-public-agencies/

Ontario Ministry of Environment. (2007). Go Green: Ontario's action plan on climate change. Retrieved from http://www.climateontario.ca/doc/workshop/2011 LakeSimcoe/Ontarios\%20Go\%20Green\%20 Action\%20Plan\%20on\%20Climate\%20Change.pdf

Ontario Ministry of Environment. (2011). Climate Ready: Adaptation strategy and action plan 2011-2014. Retrieved from https://dr6j45jk9xcmk.cloudfront.net/documents/817/2-2-5climate-ready-en.pdf

Ontario Ministry of Finance. (2013). Ontario population projections update. Retrieved from http://www.fin.gov.on.ca/en/economy/demographics/projections/projections2012-2036.pdf

Ontario Ministry of Municipal Affairs \& Housing. (2007). Development Permit System (DPS). Retrieved from http://www.mah.gov.on.ca/Page4755.aspx 
Ontario Ministry of Municipal Affairs \& Housing. (2011). Section 2: An overview of local government. Retrieved from http://www.mah.gov.on.ca/Page8391.aspx

Ontario Ministry of Municipal Affairs \& Housing. (2010). Community Improvement Plans (CIPs) (s. 28). Retrieved from http://www.mah.gov.on.ca/Page6850.aspx

Ontario Ministry of Municipal Affairs and Housing. (2014). Provincial Policy Statement 2014. Retrieved from http://www.mah.gov.on.ca/AssetFactory.aspx?did=10463

Ontario Power Authority \& IESO. (2013). Enhancing Regional Electricity Planning and Siting. Retrieved from http://www.onregional-planning-and-sitingdialogue.ca/pdf/Regional_Planning-Siting_Report.pdf

Parnis, G., Bambara, J., Kayello, A., Dermardiros,V., Chen, Y., Yang, T., \& Capsis., K. (2014, December). Montreal $3^{\text {rd }}$ Annual General meeting, Day 1 Workshops. SNERBRN Newsletter [online], p. 2. Retrieved from http://www.solarbuildings.ca/documents/SNEBRN\%203RD\%20NEWSLETTER_V2.pdf

Pitt, D. R. (2010). Harnessing community energy: the keys to climate mitigation policy adoption in US municipalities. Local Environment, 15(8), 717-729.

Prime Minister of Canada Stephen Harper (2009). Northwest transmission line in British Columbia. Retrieved from http://www.pm.gc.ca/eng/news/2009/09/16/northwesttransmission-line-british-columbia

PVResources. (n.d.). Photovoltaic noise barriers. Retrieved from http://www.pvresources.com/PVSystems/NoiseBarriers.aspx

PV Upscale. (2007).Solarsiedlung am Schlierberg, Freiburg (Breisgau), Germany. Retrieved from http://www.pvupscale.org/IMG/pdf/Schlierberg.pdf 
Quality Urban Energy Systems of Tomorrow, \& Canadian Urban Institute. (2010). Integrated community energy solutions: Municipal policy toolkit. Retrieved from http://www.questcanada.org/pdf/CUI_MPTK.pdf

Quality Urban Energy Systems of Tomorrow. (2015). National report on community energy plan implementation. Toronto, ON: Littlejohn.

Robinson, P. (2012). Planning for Sustainability: Moving from Plan to Action. In Dale, A., Dushenko, W. T., Robinson, P. (Eds.), Urban Sustainability: Reconnecting space and place (pp.83-105). Toronto: University of Toronto Press.

Rocky Mountain Institute, Homer Energy \& Cohnreznick Think Energy. (2015). The economics of grid defection: When and where distributed solar generation plus storage competes with traditional utility service.

Svekom. (2003). City of tomorrow: Malmö (SE). Task 9 of the International Energy Agency DSM Implementing Agreement, Municipalities and Energy Efficiency in a Liberalised System. Retrieved from http://www.energy-cities.eu/db/malmo_566_en.pdf

Solangi, K. H., Islam, M. R., Saidur, R., Rahim, N. A., \& Fayaz, H. (2011). A review on global solar energy policy. Renewable and sustainable energy reviews, 15(4), 2149-2163.

SolaRoad. (n.d.). SolaRoad. Retrieved from http://www.solaroad.nl/en/

SolarShare. (n.d.) SolarShare Retrieved from http://www.solarbonds.ca

Solar Heating \& Cooling Programme. (2015). Task 51: Solar energy in urban planning. Retrieved from http://task51.iea-shc.org/publications

Temby, O., Kapsis, K., Berton, H., Rosenbloom, D., Gibson, G., Athienitis, A., \& Meadowcroft, J. (2014). Building-Integrated Photovoltaics: Distributed Energy Development for Urban Sustainability. Environment: Science and Policy for Sustainable Development, 56(6), 4-17.

Timilsina, G. R., Kurdgelashvili, L., \& Narbel, P. A. (2012). Solar energy: markets, economics and policies. Renewable and Sustainable Energy Reviews, 16(1), 449-465. 
United States Department of Energy. (2010). U.S. Department of Energy convenes city leaders from 25 markets for Solar America Cities $3^{\text {rd }}$ annual meeting. Retrieved from http://apps1.eere.energy.gov/news/progress_alerts.cfm/news_id=19956

United States Department of Energy. (2011). Challenges and successes on the path toward a solar-powered community: New York City, New York. Retrieved from http://www1.eere.energy.gov/solar/pdfs/50198_newyorkcity.pdf

United States Department of Energy. (2012, September, 4). The bright lights in New York could be solar. Retrieved from http://energy.gov/articles/bright-lights-new-york-could-be-solar

Vandevyvere, H., \& Stremke, S. (2012). Urban planning for a renewable energy future: Methodological challenges and opportunities from a design perspective. Sustainability, 4(6), 1309-1328.

Van Esch, M. M. E., Looman, R. H. J., \& de Bruin-Hordijk, G. J. (2012). The effects of urban and building design parameters on solar access to the urban canyon and the potential for direct passive solar heating strategies. Energy and Buildings, 47, 189-200.

World Wildlife Fund Global. (2014, September 18). Seoul Sunlight City. Retrieved from: http://wwf.panda.org/what_we_do/footprint/cities/urban_solutions/100_cases/?229196 /Seoul-Sunlight-City 